\title{
Infections in AIDS
}

\author{
Proceedings of the Sixth Liverpool Tropical School Bayer Symposium on Microbial Diseases held on \\ 6 February 1999
}

\author{
Edited by C. A. HART, N. J. BEECHING and B. I. DUERDEN*
}

School of Tropical Medicine and Department of Medical Microbiology and Genito-urinary Medicine, University of Liverpool, PO Box 147, Liverpool L69 3GA and*Department of Medical Microbiology and Public Health Laboratory, University of Wales College of Medicine, Heath Park, Cardiff CF14 4XN

\section{Introduction}

Reports of an unusual syndrome in which previously healthy young males were presenting with diseases previously important only in immunocompromised individuals appeared in 1981 [1]. The diseases were cytomogalovirus pneumonia, Pneumocystis carinii pneumonia and Kaposi's sarcoma and the condition became known as the acquired immunodeficiency syndrome or AIDS. Since then the numbers have increased inexorably with an estimated 1736958 cumulative AIDS cases world-wide in 1997 [2]. The same survey also estimated that in Nov. 1997 there were 30.6 million people living with HIV/AIDS in the world [2]. Most of these were in subSaharan Africa (20.8 million: 68\%), South and South-East Asia (6 million: 19.6\%) and Latin America (1.3 million: 4.2\%), with smaller numbers in North America (860000: 2.8\%), Western Europe (530000: 1.7\%) and East Asia and the Pacific (440 000: 1.4\%).

Although HIV itself can produce disease manifestations, its major effect is the diminution of immunity leading to the appearance of opportunist infections and tumours. Indeed, the AIDS epidemic has resulted in the recognition of a number of new pathogens. Table 1 illustrates the range of pathogens that have been recognised as causing opportunist infections in AIDS.

Different opportunist infections or conditions present at different times in the evolution of the infection with HIV. Thus, invasive pneumococcal and non-typhoidal salmonella infections and oral candidosis present early in HIV-infected patients, especially in Africa. The appearance of chronic muco-cutaneous herpes simplex infection, oesophageal candidosis, chronic cryptosporidial diarrhoea, wasting syndrome and Kaposi's sarcoma were the commonest conditions defining entry of HIV-infected patients into WHO stage 4 (AIDS) in a Ugandan study of adults [3]. In contrast, in infants with

Received 31 March 2000; accepted 15 April 2000.

Corresponding author: Professor C. A. Hart.
AIDS, Pneumocystis carinii pneumonia is a common cause of morbidity and mortality [4], with up to $30 \%$ of children under 1 year having evidence of infection at post mortem [5].

The introduction of highly active antiretroviral therapy (HAART) has radically altered AIDS incidence in developed countries, and thus the impact of opportunist infections $[6,7]$. In the initial flush of enthusiasm over HAART some commentators even suggested that it might not just cure AIDS but also, by completely preventing HIV replication, eventually eliminate the virus as infected cells died. As might be expected these hopes have not been realised. Firstly, some of the HAART regimens have not proved as effective in children as in adults, e.g., viral loads decreased to $<400$ copies $/ \mathrm{ml}$ in as few as $20 \%$ of those treated and rebounded in as many as $44 \%$ of those successfully treated [8-10]. However, this problem has been resolved by employing different regimens (e.g., a combination of efavirenz, nelfinavir and nucleoside reverse transcriptase inhibitors) [11]. However, a larger problem is the emergence of drug-resistant mutants. During acute infection it is estimated that c. $10^{9} \mathrm{HIV}$ particles are produced per day and c. $10^{6}$ of these are mutants $[12,13]$. Thus it is clear that application of selective pressure such as antiviral chemotherapy will drive the development of resistant mutants as happened, for example, with zidovudine monotherapy [14]. Ominously, in a recent study $16 \%$ of newly diagnosed cases of HIV-1 infection were with antiretroviralresistant genotypes [15]. Combining antiretroviral agents was expected to decrease the chance of resistance developing. The administration of HAART is accompanied by a great decrease in plasma HIV load and has been shown to obviate the need for chemoprophylaxis of $P$. carinii pneumonia [16]. However, it is now clear that even with HAART, which results in undetectable plasma HIV loads, HIV transcription still persists in peripheral blood mononuclear cells. In addition, HIV may also persist in cells in semen of patients on HAART who have undetectable plasma HIV loads [18]. 
Table 1. Some opportunist pathogens in AIDS

\begin{tabular}{|c|c|c|c|c|}
\hline Viruses & Bacteria & Fungi & Protozoa & Other \\
\hline $\begin{array}{l}\text { Human herpesviruses } 1-5 \\
\& 8 \\
\text { Human papillomavirus } \\
\text { JC virus } \\
\text { Molluscum contagiosum }\end{array}$ & $\begin{array}{l}\text { Anaerobes } \\
\text { Bartonella henselae } \\
\text { B. quintana } \\
\text { Bordetella bronchiseptica } \\
\text { Campylobacter spp. } \\
\text { Chlamydia trachomatis } \\
\text { Clostridium difficile } \\
\text { Haemophilus influenzae } \\
\text { Legionella pneumophila } \\
\text { Listeria monocytogenes } \\
\text { Moraxella catarrhalis } \\
\text { Mycobacterium tuberculosis } \\
\text { M. avium intracellulare } \\
\text { M. fortuitum } \\
\text { M. kansasii } \\
\text { M. marinum } \\
\text { Neisseria gonorrhoeae } \\
\text { Nocardia asteroides } \\
\text { Rhodococcus equi } \\
\text { Salmonellae (non-typhi) } \\
\text { Shigella spp. } \\
\text { Staphylococcus aureus } \\
\text { Streptococcus pneumoniae } \\
\text { Treponema pallidum }\end{array}$ & $\begin{array}{l}\text { Aspergillus spp. } \\
\text { Candida albicans } \\
\text { Candida spp. } \\
\text { Coccidiodes immitis } \\
\text { Cryptococcus neoformans } \\
\text { Blastomyces dermatidis } \\
\text { Dermatophytes } \\
\text { Cryptococcus neoformans } \\
\text { Histoplasma capsulatum } \\
\text { Malessazia furfur(?) } \\
\text { Mucor pusillus } \\
\text { Penicillium marneffei } \\
\text { Pneumocystis carinii } \\
\text { Sporothrix schenckii }\end{array}$ & $\begin{array}{l}\text { Acanthamoeba spp. } \\
\text { Cryptosporidium parvum } \\
\text { Entamoeba histolytica } \\
\text { Giardia lamblia } \\
\text { Isospora belli } \\
\text { Microsporidia } \\
\text { Toxoplasma gondii }\end{array}$ & $\begin{array}{l}\text { Sarcoptes scabiei } \\
\text { Strongyloides stercoralis }\end{array}$ \\
\hline
\end{tabular}

The presence of HIV replication in privileged sites such as seminal cells and CSF and even peripheral blood mononuclear cells during HAART allows the possibility of development of resistant mutants. Although none was detected in the systematic studies of HIV persistence in HAART [17-19], mutants resistant to reverse transcriptase inhibitors (nucleoside and non-nucleoside) and protease inhibitors have been detected [20, 21]. This problem can be ameliorated to a certain extent by using resistance genotyping to guide initiation and changes in combination therapies [22]. Nevertheless, even with ostensibly sensitive HIV, HIV load is not reduced to undetectable levels in up to $10 \%$ of patients and $20 \%$ experience viral load rebound [23]. Interestingly, such virological failures were not necessarily associated with clinical progression of AIDS, but such occurrences are bound to increase the risk of resistance developing.

Although in developed countries the incidence of opportunist infections has greatly diminished following the introduction of HAART, it is clear that this may not always be the case. Furthermore, in tropical countries where the greatest burden of HIV disease occurs, HAART is unfortunately not affordable and opportunist infections abound. Therefore, it seemed appropriate to have infections in AIDS as the theme of the sixth symposium on microbial disease.

\section{MICROSPORIDIOSIS}

Alan Curry

Public Health Laboratory, Withington Hospital, Manchester, M20 2LR

Microsporidia are regarded as almost ubiquitous in the wild, particularly amongst invertebrates [24] and fish
[25], but some have also been described in birds and mammals [25]. Some were known to cause significant economic loss to commercial producers of honey, silk and fish if their animal stocks were infected. Against this widespread occurrence in nature, only a handful of human infections had been documented before 1985 and so this group of parasites had been largely ignored by the medical world. However, this paradox has now evaporated with the advent of AIDS and the recognition of HIV infection, as significant numbers of human infections involving these parasites have become recognised. Many of these infections involve species that were previously unknown. Interestingly, as a recent study has shown a high seroprevalence to Encephalitozoon spp. in the immunocompetent population [26], subclinical infection or infection involving mild, transient symptoms may be common in man.

Microsporidiosis comprises a group of infectious diseases caused by microsporidia that occur predominantly, but not exclusively, in human patients with AIDS. So, what are microsporidia? Microsporidia are small, unicellular, obligately intracellular parasites that are transmitted as highly resistant spores. The spores contain the infective sporoplasm and a coiled tube (the polar tube) with associated extrusion apparatus, the presence of which is pathognomonic of microsporidial infection. On entering a suitable host, the polar tube is everted and penetrates a susceptible host cell. The sporoplasm migrates through the everted polar tube and is injected into the host cell cytoplasm. Replication is a two-stage process, initially involving repeated proliferation (merogony) before commitment to spore production (sporogony). About 1000 species are known currently, but this is thought to be a gross underestimate of the total number of species within the phylum Microspora [24]. Indeed, new species are still 
being described from many hosts at a significant rate, year on year.

Chronic diarrhoea, malabsorption and wasting are common presentations in AIDS patients. In 1985, Enterocytozoon bieneusi (Fig. 1) was first described [27] and this microsporidian has become recognised as the commonest microsporidian species reported to occur in man. Most infections either occur or become clinically significant when the CD4 lymphocyte count falls below $100 \times 10^{6} / \mathrm{L}$ [28]. A second enteric species, Encephalitozoon (Septata) intestinalis, was described in 1993 [29] and dual infections involving both these species have been reported [30]. Ent. bieneusi is normally restricted to the small intestinal enterocytes, whereas E. intestinalis spreads into the lamina propria [29]. Both these species have been found to spread from the intestine along the epithelium to the gall bladder and the pancreatic and bile ducts $[29,31]$. Although rarer, spread to the respiratory system has been documented with both species [31,32]. Most studies [33, 34], but not all [35], have shown an association between enteric infection and symptoms of diarrhoea and weight loss.

Several microsporidial infections of the eyes have been reported (Table 2). In AIDS patients, ocular involvement is often the presenting sign of microsporidiosis. Infection of corneal and conjunctival epithelia commonly involves E. hellem (Fig. 2) [36], but $E$. intestinalis, E. cuniculi and Trachipleistophora hominis have also been reported. These infections cause a bilateral punctate keratopathy (keratoconjunctivitis) [37]. E. hellem has also been reported from the lungs [38], which may be the source of some ocular

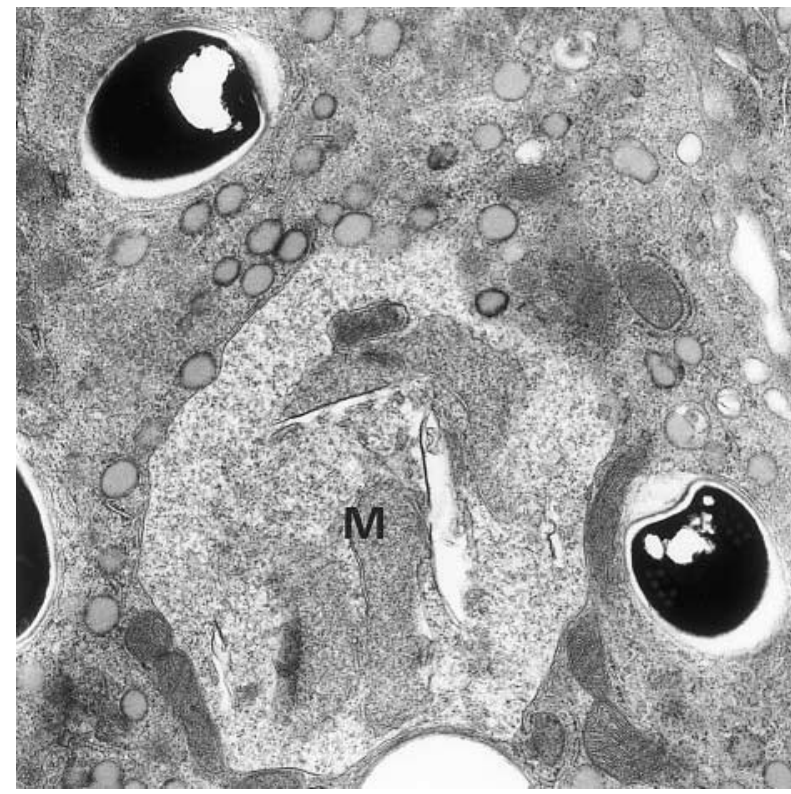

Fig. 1. Enterocyte from a small intestinal biopsy from an AIDS patient infected by Enterocytozoon bieneusi showing spores (densely stained) and a merogonic stage (M). Note that this parasite is in intimate contact with the host cell cytoplasm. Magnification $16000 \times$.
Table 2. Species and sites of microsporidial infections in man

\begin{tabular}{|c|c|}
\hline Organism & Main sites of infection \\
\hline Enterocytozoon bieneusi & $\begin{array}{l}\text { Small intestinal epithelium, bile } \\
\text { duct epithelium and, rarely, nasal } \\
\text { polyps and bronchial epithelium }\end{array}$ \\
\hline Encephalitozoon cuniculi & $\begin{array}{l}\text { Liver, peritoneum, kidney, intestine, } \\
\text { eyes }\end{array}$ \\
\hline Encephalitozoon hellem & $\begin{array}{l}\text { Corneal and conjunctival epithelia, } \\
\text { nasal polyps, kidney, } \\
\text { tracheobronchial tree }\end{array}$ \\
\hline $\begin{array}{l}\text { Encephalitozoon intestinalis } \\
\text { (syn. Septata intestinalis) }\end{array}$ & $\begin{array}{l}\text { Epithelia of the gut from small } \\
\text { intestine to colon, macrophages in } \\
\text { the lamina propria, kidney, eyes and } \\
\text { gall bladder }\end{array}$ \\
\hline Trachipleistophora hominis & $\begin{array}{l}\text { Skeletal muscle, heart muscle, } \\
\text { corneal epithelium, kidney, } \\
\text { nasopharynx }\end{array}$ \\
\hline $\begin{array}{l}\text { Trachipleistophora } \\
\text { anthropophthera }\end{array}$ & $\begin{array}{l}\text { Brain, kidney, heart, pancreas, } \\
\text { thyroid, parathyroid, liver, spleen, } \\
\text { bone marrow }\end{array}$ \\
\hline Pleistophora spp. & Skeletal muscle \\
\hline Brachiola vesicularum & Skeletal muscle \\
\hline $\begin{array}{l}\text { Brachiola connori (synonym } \\
\text { for } N \text {. connori) }\end{array}$ & $\begin{array}{l}\text { Disseminated, defective lymphoid } \\
\text { system, smooth and cardiac muscle, } \\
\text { kidney, liver, lungs, adrenal cortex }\end{array}$ \\
\hline $\begin{array}{l}\text { Vittaforma corneae (syn. } \\
N . \text { corneum) }\end{array}$ & Corneal stroma of the eye \\
\hline Nosema ocularum & Corneal stroma of the eye \\
\hline 'Microsporidium' ceylonensis & Corneal stroma of the eye \\
\hline 'Microsporidium' africanum & Corneal stroma of the eye \\
\hline
\end{tabular}

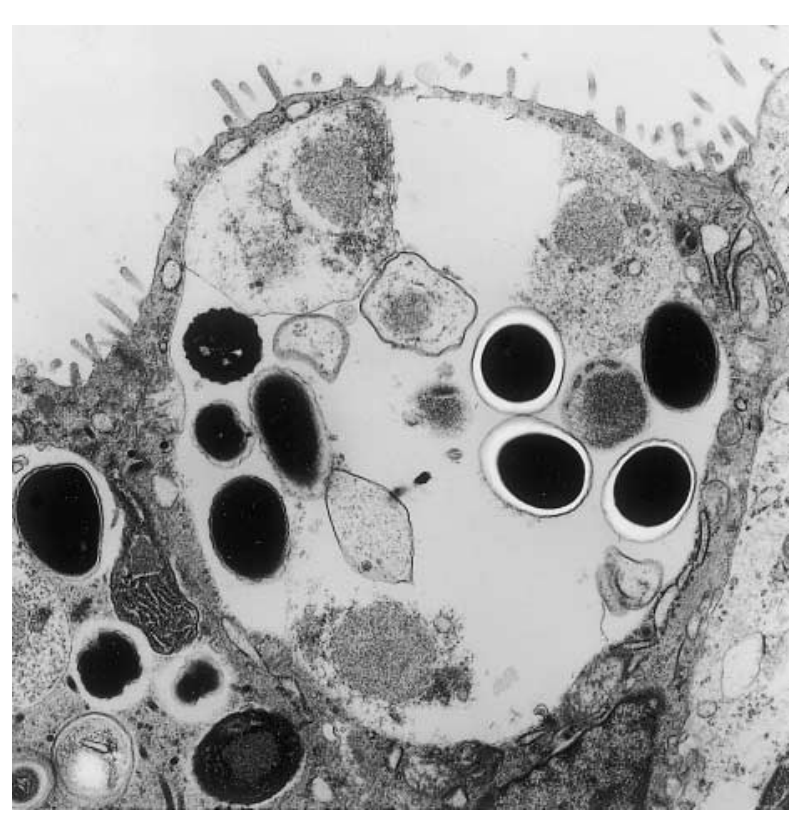

Fig. 2. Nasal epithelium from an AIDS patient showing various stages in the development of Encephalitozoon hellem. Note that development is undertaken in a parasitophorous vacuole. Magnification $8000 \times$.

infections by reverse passage from this respiratory site of infection [39]. Of the reported stromal infections, most have been unrelated to HIV infection [25]. However, Vittaforma corneae [40] was originally isolated from an immunocompetent patient (as Nosema corneum [41]) and infection was established in athymic mice [42]. On this basis, it was predicted that $V$. corneae could become established in immunosuppressed human patients [42] and this species has recently been reported from an AIDS patient [43]. 
Another presentation can be myositis. Pleistophora-like species [44, 45], T. hominis (Fig. 3) [46, 47], Brachiola vesicularum and $B$. connori [48] infections produce symptoms of severe muscle pain and weakness. Such microsporidial infection is associated with myocyte destruction. T. hominis and B. vesicularum have only recently been described. Only in the case of $B$. vesicularum was infection restricted to skeletal muscle. A second species of Trachipleistophora, T. anthropopthera, is the latest microsporidian to be described in man. The parasite was found in the brain of two AIDS patients [49], a site of infection that has been documented infrequently in previous human microsporidial infections. Currently, about 13 microsporidian species have been identified in man (Table 2), most, but not all, associated with HIV infection. These parasites are now known to infect individual organs such as gut, eyes, brain, skeletal muscle, heart, tracheobronchial tree, liver, kidneys and genitourinary tract, producing a variety of clinical symptoms, such as diarrhoea, cholangitis, bronchitis, sinusitis, keratoconjunctivitis, hepatitis, myositis, encephalitis, nephritis and urethritis $[31,50]$. Other sites of infection and associated symptoms are likely to be found with human microsporidial infection. Disseminated infection is now widely recognised $[29,31,51]$ and without treatment such infection can be significantly debilitating and may have a fatal outcome. The possibility of disseminated infection should be considered particularly if species of Encephalitozoon are diagnosed [38]. The mechanism of dissemination is not understood, but is thought to involve macrophages [51].

As might be expected from the nature and course of HIV infection, antibodies appear to be significantly less protective than the cell-mediated immune response in

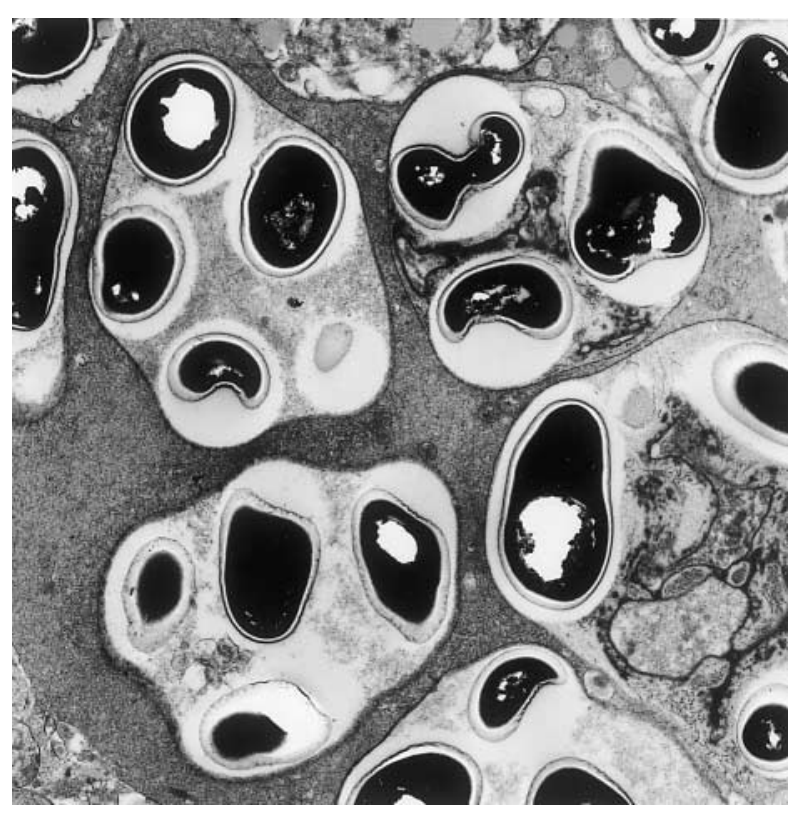

Fig. 3. Pectoral muscle from an AIDS patient showing sporophorous vesicles (SPOVs) containing spores of Trachipleistophora hominis. Magnification $6500 \times$. controlling microsporidial infections [38]. Experimental infections in athymic mice have confirmed this view [52].

One of the most fascinating aspects of microsporidial infection in man is the determination of possible sources of such infections. Contaminated food and water are likely vehicles of transmission to man by the faecal-oral or urine-oral route, but sources of human microsporidial infection remain largely obscure. Acquisition through the respiratory epithelium has also been suggested [53], as has introduction through eye abrasions [39]. Some may be natural human parasites, but animal sources are likely for the rest. Some human microsporidial infections may result from rare accidental exposure to microsporidial spores (such as in infected fish muscle) and only become established if the human host is immunocompromised. Species of Pleistophora are common muscle infections in fish [25] and crustacea (shrimps and crabs) [24] and such food sources may account for the small number of human microsporidial muscle infections involving Pleistophora-like species identified to date [44-46]. Some microsporidia, such as E. cuniculi, infect many mammals, particularly rodents, rabbits and dogs [25]. E. cuniculi infection in one AIDS patient was confirmed to be a dog strain by molecular methods, which indicates that some pets may be a potential source of human infection [54]. Other pets, such as caged birds, may be sources of infection, as E. hellem has recently been identified in the intestinal epithelium of budgerigars [55] and in the intestine and also the kidneys of parrots [56]. Interestingly, the parrots were co-infected with a virus that induced immunosupression [56]. As the E. hellem infection in these birds involved the intestine, the potential for human contact with droppings containing spores is self-evident. As such droppings are generally dry, or dry quickly after being voided, inhalation of dust containing spores into the respiratory tract is a distinct possibility. Pets can and do provide a source of comfort to their human owners but, perhaps, caring for certain pet animals (such as dogs [54], rabbits [57] and caged birds $[55,56])$ should be discouraged if the individual is HIV-infected. However, with a high seroprevalence for some microsporidian species, particularly Encephalitozoon spp. [26] and the possibility of reactivation of latent infection [58], then perhaps this advice is only pertinent in preventing exposure to potential new sources of infection involving animal species. Faeces from domestic farm livestock, including donkeys, pigs, cows and goats, have recently been shown to contain spores of E. intestinalis in a study in a rural village in Mexico [59]. The commonest human microsporidian parasite, Ent. bieneusi, has been identified in both pigs [60] and macaque monkeys with simian AIDS [61], but neither of these sources could explain the high prevalence in AIDS patients. The demonstration of four genetically diverse variants of Ent. bieneusi [62] suggests that much remains to be learned about the 
epidemiology and host range of this parasite. The possibility that these animal infections have been acquired from their human handlers also needs to be examined. Another possibility is transmission of microsporidia from arthropod sources, particularly blood-sucking or biting insects. Whether microsporidia from such poikilothermic sources can infect warmblooded mammals, such as man, has not been determined. However, as a microsporidian parasite of mosquitoes has been successfully transmitted to mice, this may be a possibility, particularly in immunosuppressed individuals [63]. Work in this area is still at an early stage and is summarised in Table 3.

Diagnosis of microsporidial infections in tissue biopsies can be difficult because of their small size, intracellular nature and poor staining properties with normal histological stains. Transmission electron microscopy (TEM) can be useful here, but availability may be a problem [34]. Spores of Ent. bieneusi are the smallest reported to infect man, being only $c$. $1.8 \times 1 \mu \mathrm{m}$. Such spores can be detected in faeces or body fluids by means of calcofluor [64] or trichrome stains [65]. Some workers have advocated using calcofluor as a screening stain, followed by trichrome as a confirmatory stain [66]. Where specialised laboratory techniques are unavailable, this is acceptable, but a significant disadvantage of these light microscopy methods is that the species involved cannot be determined. Species determination is important as some infections can be treated successfully, whereas others involving different species may not (see below). Availability of commercial, species-specific fluoresceinlabelled antibodies would be a significant advantage here and some are becoming available [67]. Electron microscopy or molecular methods should be used as confirmatory tests, if available. Most workers utilising molecular diagnostic methods in the field of microsporidial detection have amplified parts of the small subunit ribosomal RNA gene [68]. Continued use of molecular techniques, such as PCR, will significantly improve our knowledge of the pathogenesis, epidemiology and phylogeny of these opportunist parasites.

Some microsporidial infections (particularly those involving Encephalitozoon spp.) are treatable with the

Table 3. Human microsporidian species and identified animal hosts

\begin{tabular}{|c|c|}
\hline Organism & Animal host \\
\hline Enterocytozoon bieneusi & $\begin{array}{l}\text { Domestic pigs, Macaque monkeys with } \\
\text { SAIDS }\end{array}$ \\
\hline Encephalitozoon cuniculi & $\begin{array}{l}\text { Wide host range among mammals, } \\
\text { including rodents, rabbits and dogs }\end{array}$ \\
\hline Encephalitozoon hellem & Budgerigars, parrots \\
\hline $\begin{array}{l}\text { Encephalitozoon intestinalis } \\
\text { (syn. Septata intestinalis) }\end{array}$ & Dog, donkey, pig, cow and goat \\
\hline Pleistophora spp. & Many fish and crustacea \\
\hline
\end{tabular}

current treatment of choice, albendazole [69-71]. Albendazole inhibits polymerisation of the intranuclear spindle microtubules during nuclear division, thus preventing chromosome separation. Parasite division is thus inhibited, but this does not appear to have a parasitocidal action [72]. However, in human patients, infection with Encephalitozoon spp. can be treated successfully [73] but Ent. bieneusi, in particular, is often refractory to treatment (although there can be symptomatic improvement) and more effective treatment is required. Several new compounds show promise [74]. Fumagillin has been used topically to treat eye infections caused by E. hellem [75] but was thought to be too toxic for treatment of other human microsporidial infections. However, in a recent trial fumagillin successfully eradicated infection due to Ent. bieneusi but caused thrombocytopenia in the treated patients [76]. A semisynthetic analogue of fumagillin, TNP-470, which is less toxic, has also been shown to be effective against E. cuniculi in infected cell culture and an athymic nude mouse model [77]. A controversial drug from the past, thalidomide, also appears to have anti-microsporidial activity [78]. Faecal tumour necrosis factor-alpha (TNF- $\alpha$ ) is elevated in AIDS patients with enteric microsporidial infection. In one trial, thalidomide, a potent anti-TNF- $\alpha$ agent, was shown to effect a complete or partial clinical response in over half the AIDS patients with chronic diarrhoea due to Ent. bieneusi who were treated.

With the recent improvements in antiretroviral treatment of AIDS patients [79] in the developed world, degradation of the cellular immune system has been halted and reconstitution has had a significant downward effect on opportunist parasite prevalence rates [80]. A study from the UK, based on data from 1992 to 1995 , showed a prevalence rate of the enteric parasite Ent. bieneusi in AIDS patients of c. 15\% [34], but other studies have shown higher rates. This UK-based study ended in Dec. 1995 and only a single further case has been diagnosed to date from the same source (unpublished observations). This decrease appears to correlate with the improved antiretroviral treatment now administered to AIDS patients [79]. If these improved treatment regimens remain effective, occurrence of such opportunist infections will remain low. Such a reduction in opportunist infections will, of course, affect the demand for newer (PCR-based) diagnostic tests and thus the occasional suspected infection will be diagnosed only by conventional microscopic methods. However, in the developing world the situation is very different and is a cause for concern [79].

Much remains to be learned about this group of emerging pathogens in relation to human infection and disease. Even basic information such as the incubation period of the various species of parasites in man is not known. Most of the current knowledge about human microsporidial infections has come from AIDS pa- 
tients. Patients who become immunosuppressed from other causes, such as malignancy or its treatment or organ transplantation, are also becoming recognised as potential hosts for microsporidia [81-83]. Because diagnostic methods have been developed and workers are now looking for them, microsporidia are also being recognised increasingly in the immunocompetent population, particularly in relation to traveller's diarrhoea, where both Ent. bieneusi [84,85] and E. intestinalis [86] have been identified. Such cases suggest that enteric microsporidial infections, at least, may be much commoner causes of sporadic diarrhoea than has been suspected previously. The field of microsporidial research, particularly in relation to human infection, is a rapidly expanding field of interest and we can expect many more interesting developments in the near future.

\section{INVASIVE PNEUMOCOCCAL DISEASE IN HIV- INFECTED ADULTS}

Neil French

Liverpool School of Tropical Medicine, University of Liverpool, Liverpool L69 $3 G A$

\section{Introduction}

Streptococcus pneumoniae is an important and dangerous infectious complication of HIV infection, and together with non-typhoidal salmonellae the most important complicating bacterial pathogen. S. pneumoniae-related illness was absent from the earliest descriptions of AIDS in North America. However, with the ability to detect HIV infection before AIDS and the introduction of anti-retroviral agents and prophylactic therapies, the spectrum of HIV/AIDSrelated illness has changed. The incidence of Pneumocystis carinii pneumonia (PCP) has fallen, and bacteria, most importantly $S$. pneumoniae, have played an increasingly important role [87-90] Bacterial pneumonia is now amongst the leading causes of HIV-related admission to hospital in the USA [91-97]

The association of HIV and $S$. pneumoniae in the developing world is now similarly well recognised [98102]. Respiratory disease has been, and is, highly prevalent in HIV-infected adults. S. pneumoniae and Mycobacterium tuberculosis are the leading causes of respiratory illness. Moreover, it is in the developing world where treatment and control of pneumococcal infection are perhaps of greatest importance and present the greatest challenge. The number of HIVinfected adults is large and growing, inadequate secondary health care limits access to appropriate therapy and antimicrobial resistance will continue to develop and spread, the impact of which is worryingly uncertain.

S. pneumoniae is implicated in various clinical syndromes. It is the most frequent bacterial cause of otitis media, sinusitis and bronchitis [103, 104]. However, it is the invasive syndromes of necrotising pneumonia, bacteraemia and meningitis to which HIV-infected individuals are particularly susceptible, and it is these syndromes which are responsible for the preponderance of $S$. pneumoniae-related mortality. The presentation and management of these serious invasive infections form the focus of this review.

\section{Epidemiology of $S$. pneumoniae and HIV infection}

Rates of bacterial pneumonia in HIV-infected adults are increased 5-10-fold compared with age-matched controls $[90,94,105,106]$. S. pneumoniae is invariably the commonest causative agent [94, 96, 107-109]. More importantly, blood stream infection complicates 60$80 \%[90,92,96,98,99,110,111]$ of such cases (compared with $10-20 \%$ in HIV-uninfected patients $[112,113])$ Consequently, bacteraemic pneumococcal disease is between 20 and 100 times more common with HIV/AIDS. In the developing world and amongst intravenous drug users (IVDU), rates of disease may be even higher than those reported amongst homosexual groups in North America [90, 94, 96, 97, 99, 100, 102, 105, 106, 109-11, 115-18] (Table $4)$. In these groups the environmental and social problems that exist and predispose to increased rates of disease in the HIV-uninfected population are simply compounded by infection with HIV.

Rates of disease increase with advancing immunosuppression. Individuals with AIDS have a three-to-five times greater risk than individuals with asymptomatic HIV infection [95, 111, 119]. Whether reversal of immunosuppression with HAART will decrease the risk of infection is as yet unknown. The recovery of some cellular immune function with this therapy may not translate into improved B-cell function.

Given appropriate access to health care, case fatality rates are similar in HIV-infected and uninfected individuals. Indeed, in North America and Europe the outcome with HIV is better than in age-matched uninfected controls (Table 4). This is probably a consequence of the serious nature of other complicating illnesses in the HIV-uninfected group, i.e., transplant recipients, diabetes mellitus, renal failure, neoplasia, etc. The situation in subSaharan Africa is different. Presentation for treatment tends to be late and casefatality is high irrespective of HIV status [100, 107].

Recurrence of $S$. pneumoniae infection is frequent. Whilst this phenomenon is not unique to HIV, it occurs at a strikingly high rate. Annual recurrence rates following an episode of invasive infection are between 10 and $30 \%$, and are usually re-infections with different serotypes $[99,110]$. The high rate may reflect a subpopulation of HIV-infected individuals who are 


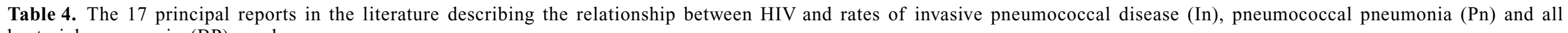
bacterial pneumonia (BP) syndromes

\begin{tabular}{|c|c|c|c|c|c|c|c|c|c|}
\hline Ref. No. & Site & Type of study & Date & $\begin{array}{l}\text { Characteristics/ } \\
\text { HIV status }\end{array}$ & Syndrome & Rate & $\mathrm{n}$ & Mortality & Recurrence \\
\hline 90 & New York & Prospective & $1985-86$ & $\begin{array}{c}+ \text { non-AIDS IVDU } \\
- \text { IVDU }\end{array}$ & Pn & $\begin{array}{r}34.6 \\
3.5\end{array}$ & $\begin{array}{l}5 \\
1\end{array}$ & $\begin{array}{l}0 \\
0\end{array}$ & $\ldots$ \\
\hline 99 & Nairobi & Prospective & $1989-92$ & $\begin{array}{l}+\mathrm{CSW} \\
-\mathrm{CSW}\end{array}$ & In & $\begin{array}{c}23.8 \\
0\end{array}$ & $\begin{array}{r}42 \\
0\end{array}$ & $\begin{array}{l}0 \\
-\end{array}$ & 19 \\
\hline 105 & Rome & Prospective & $1991-94$ & $\begin{array}{l}+ \text { IVDU } \\
+ \text { IVDU } \\
- \text { IVDU } \\
- \text { IVDU }\end{array}$ & $\begin{array}{l}\mathrm{Pn} \\
\mathrm{BP} \\
\mathrm{Pn} \\
\mathrm{BP}\end{array}$ & $\begin{array}{r}18.6 \\
90.5 \\
1.2 \\
14.2\end{array}$ & $\begin{array}{r}30 \\
149 \\
5 \\
61\end{array}$ & $\begin{array}{l}- \\
- \\
- \\
-\end{array}$ & $\begin{array}{r}10 \\
21 \\
0 \\
2\end{array}$ \\
\hline 110 & San Francisco & Retrospective community & $1983-87$ & $\begin{array}{l}+ \text { Homosexual } \\
- \text { Age } 20-55\end{array}$ & In & $\begin{array}{l}9.4 \\
0.12\end{array}$ & $\begin{array}{r}75 \\
219\end{array}$ & $\begin{array}{r}8 \\
18\end{array}$ & $\begin{array}{r}13 \\
7\end{array}$ \\
\hline 111 & New Jersey & Retrospective Community & 1986 & $\begin{array}{l}\text { AIDS-mixed } \\
\text { Pre-AIDS-mixed } \\
- \text { Age } 20-55\end{array}$ & In & $\begin{array}{l}10.7 \\
5.3 \\
0.03\end{array}$ & $\begin{array}{c}17 \\
- \\
\mathrm{nr}\end{array}$ & $\begin{array}{c}6^{*} \\
- \\
11\end{array}$ & $\begin{array}{l}10 \\
\cdots \\
\ldots\end{array}$ \\
\hline 114 & Madrid & Retrospective hospital & $1988-90$ & $\begin{array}{c}+ \text { mixed } \\
\text { - hospital control }\end{array}$ & Pn & & $\begin{array}{l}21 \\
54\end{array}$ & $\begin{array}{r}5 \\
5 \\
19\end{array}$ & $\begin{array}{l}\cdots \\
\cdots \\
\cdots\end{array}$ \\
\hline 115 & New York & Retrospective hospital & $1989-90$ & $\begin{array}{c}+ \text { mixed } \\
- \text { hospital control }\end{array}$ & $\begin{array}{l}\text { In } \\
\text { Pn }\end{array}$ & & $\begin{array}{l}26 \\
24\end{array}$ & $\begin{array}{l}31^{\dagger} \\
25\end{array}$ & $\begin{array}{l}\ldots \\
\ldots\end{array}$ \\
\hline 116 & Denver & Retrospective hospital & $1985-94$ & $\begin{array}{c}+ \text { mixed } \\
- \text { hospital control }\end{array}$ & In & $\begin{array}{l}\text { na } \\
\text { na }\end{array}$ & $\begin{array}{l}40 \\
74\end{array}$ & $\begin{array}{l}8 \\
5\end{array}$ & $\begin{array}{l}13 \\
\ldots\end{array}$ \\
\hline 117 & New Haven & Retrospective hospital & $1992-93$ & $\begin{array}{c}+ \text { mixed } \\
\text { - hospital control }\end{array}$ & In & & $\begin{array}{l}25 \\
81\end{array}$ & $\begin{array}{l}13 \\
12\end{array}$ & $\begin{array}{l}\cdots \\
\ldots\end{array}$ \\
\hline 102 & Johannesburg & Retrospective hospital & 1996 & $\begin{array}{c}+ \text { heterosexual } \\
- \text { hospital control }\end{array}$ & In & & $\begin{array}{l}58 \\
71\end{array}$ & $\begin{array}{l}12 \\
21\end{array}$ & $\begin{array}{l}\cdots \\
\cdots\end{array}$ \\
\hline 96 & New York & Retrospective hospital & 1986 & $\begin{array}{c}+ \text { AIDS } \\
- \text { CDC estimate }\end{array}$ & Pn & $\begin{array}{r}17.9 \\
2.6\end{array}$ & & & . \\
\hline 100 & Addis Ababa & Prospective & $1987-89$ & $\begin{array}{c}+ \text { mixed } \\
- \text { hospital control }\end{array}$ & BP & & $\begin{array}{r}9 \\
101\end{array}$ & $\begin{array}{l}11 \\
11\end{array}$ & $\begin{array}{l}\ldots \\
\ldots\end{array}$ \\
\hline 118 & Denver & Prospective & 1991 & $\begin{array}{l}+ \text { mixed } \\
+ \text { mixed } \\
+ \text { mixed }\end{array}$ & $\begin{array}{l}\text { In } \\
\text { Pn } \\
\text { BP }\end{array}$ & $\begin{array}{l}9.4 \\
20 \\
106\end{array}$ & & & $\begin{array}{l}\ldots \\
\cdots \\
\cdots\end{array}$ \\
\hline 106 & Amsterdam & Prospective & 1991 & $\begin{array}{l}+ \text { IVDU } \\
- \text { IVDU }\end{array}$ & $\mathrm{BP}$ & $\begin{array}{r}290 \\
90\end{array}$ & & & $\begin{array}{l}\cdots \\
\cdots\end{array}$ \\
\hline 97 & New York & Prospective & $1988-91$ & $\begin{array}{l}+ \text { mixed } \\
- \text { at risk }\end{array}$ & BP & $\begin{array}{r}48 \\
6\end{array}$ & $\begin{array}{r}53 \\
1\end{array}$ & $\begin{array}{r}26 \\
0\end{array}$ & $\ldots$ \\
\hline 94 & N. America & Prospective & $1988-91$ & $\begin{array}{l}+ \text { mixed } \\
- \text { at risk }\end{array}$ & BP & $\begin{array}{r}55 \\
9\end{array}$ & $\begin{array}{r}181 \\
5\end{array}$ & $\begin{array}{l}31 \\
20\end{array}$ & 6 \\
\hline 109 & Rome & Retrospective case control & 1996 & + IVDU & BP & & $\begin{array}{r}28 \\
5\end{array}$ & 23 & \\
\hline
\end{tabular}

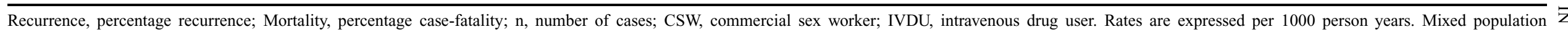
infers all methods of transmission represented.

${ }^{\dagger} 57 \%$ with AIDS died compared with $5 \%$ in non-AIDS

Partners of HIV-infected individuals. 
unable to mount an effective immune response to polysaccharide antigens and, therefore, have repeated infections. Alternatively, polysaccharide antigens may have a negative impact on B-cell populations by stimulating apoptosis and increasing the susceptibility to further infection. Irrespective of mechanism, the high risk of further disease makes individuals who have had a first episode of $S$. pneumoniae infection a prime target for preventive therapy.

\section{Clinical presentation}

S. pneumoniae-related disease is similar in presentation to that in HIV-uninfected adults. Symptoms appear acutely, chest signs are usually present and there is often production of purulent mucoid sputum. These features help to set it apart from PCP, which is a more subacute process often lacking focal chest signs. However, differentiation from tuberculosis may be more difficult, as this may follow a rather atypical and acute presentation, particularly in advanced HIV. In such situations microbiological assessment is essential.

The radiographic appearance of $S$. pneumoniae infection also follows a conventional pattern. A review of 200 cases of bacteraemic pneumococcal pneumonia in HIV-infected and uninfected patients presenting to the Kenyatta hospital in Kenya revealed no significant difference in radiographic appearance between the two groups (unpublished data). The findings were typically those of lobar pneumonia. However, these radiographic findings are also seen in tuberculosis, reinforcing the need to consider carefully the possibility of this infection presenting atypically as lobar pneumonia. Indeed, in the tropics it is not uncommon to find the two infections together.

What is different about $S$. pneumoniae infection in HIV is the increased proportion of non-pulmonary infections leading to invasive disease. Maxillary sinusitis, otitis media and primary occult bacteraemia account for as much as $40 \%$ of the invasive episodes [99,110,120]. Moreover, presentations which have become rare in the antibiotic era, i.e., endocarditis, brain abscess, mediastinitis have been reported in HIV-infected individuals [121-123].

\section{Management}

\section{Treatment}

Response to penicillin-based therapy is usually good, although early treatment is critical. Prompt management of infection in a cohort of HIV-infected commercial sex workers in Nairobi, Kenya where case-fatality rate was running at $15 \%$ reduced mortality to zero [99]. This suggests that a high index of suspicion and aggressive early therapy with penicillin are the keys to good outcome and are achievable even under resource-limited settings. Nevertheless, deaths will still occur. These will usually be in the first $24 \mathrm{~h}$ and are a consequence of the established features of sepsis syndrome and the irreversible inflammatory cascade set in motion by the bacterium and its products. Early reports that this was not a feature of pneumococcal sepsis in HIV-infected adults are probably not true, and certainly not the author's experience.

Penicillin resistance is becoming increasingly widespread and is a particular problem in HIV infection. Rates of carriage of antibiotic-resistant S. pneumoniae are higher, as are rates of infection with penicillinresistant bacteria in HIV-infected individuals $[102,108,114,117,124-126]$. Despite this, there is little evidence to suggest that outcome is worse in those infected with penicillin-resistant strains. Most resistance is of the intermediate type giving reduced susceptibility and the tissue concentrations achievable with parenteral and oral penicillin antibiotics are likely to achieve bacterial killing. However, antibiotic resistance has tended to be studied in the developed world where bacterial sensitivity testing is widely available and there is ease of access to alternative agents for treatment. The scale of the problem in the developing world is unclear. What little information there is suggests that it is growing, but still predominantly one of reduced susceptibility rather than frank resistance. The loss of penicillins as effective agents against $S$. pneumoniae would be devastating for the management of these infections in resource-poor countries.

\section{Prophylaxis}

Prevention of $S$. pneumoniae infection is attractive for several reasons. Rates of disease are high, there is significant associated morbidity and mortality with infection and any inflammatory process may have a negative impact on immune control of HIV. Several methods have been proposed. Vaccination-based strategies have been predicated on the principle that capsule-specific opsonising immunoglobulins are critical to defence against $S$. pneumoniae and that raising levels will provide protection.

Passive vaccination with pooled immunoglobulin. This has been shown to work in symptomatic HIV-infected children but has not been studied in adults [127]. However, expense and the difficulties of administration preclude its use anywhere other than in specialist centres. Moreover, it is a hopelessly impractical approach for the developing world where most cases of paediatric and adult HIV exist.

Active vaccination with polyvalent pneumococcal polysaccharide vaccines. The 23-valent pneumococcal vaccine has been available since the early 1980s. $S$. 
pneumoniae of vaccine-preventable capsular serogroups account for $90 \%$ of invasive isolates in the HIVinfected population irrespective of geography, so the vaccine developed for North America should also be applicable to the developing world $[99,116,117$, $126,128]$. It has been recommended as a standard of care for HIV-infected adults since 1991 in the UK and since 1989 in the USA. Unfortunately, these recommendations are not based on evidence of vaccine efficacy. Immunological studies have shown that HIVinfected adults can mount a response to polysaccharides contained in the vaccine, although the response is invariably much inferior to that in HIV-uninfected controls [129-134]. The only prospective, blinded and randomised efficacy trial of pneumococcal vaccine in HIV-positive patients has been completed recently in Uganda. The preliminary results of this study suggest that vaccination is ineffective. Indeed, there is some evidence to suggest that vaccination may have increased the risk of $S$. pneumoniae infections and pneumonic illness, casting serious doubts over the safety and use of the vaccine [120]. No data as yet exist on the role of the newer conjugate pneumococcal vaccines. The little work that has been done suggests that the serological response to these vaccines is also poor, although this does not necessarily equate with poor clinical efficacy [135]. Other proposed vaccines based on bacterial peptides are under development; however, the likely cost of such products, if they prove clinically valuable, will put them out of reach of developing countries.

Chemoprophylaxis. This approach has been in widespread use in other groups at increased risk of pneumococcal infection, particularly in individuals with asplenia and sickle cell disease. Penicillin either taken daily or given as monthly injections has been the preferred means of prophylaxis; however, this has not been widely used in HIV infection and there is little published work to support its use. Evidence from casecontrol studies of co-trimoxazole (used for PCP prophylaxis) does not show a clear benefit with this agent in protecting against bacterial pneumonia [94, 109, 136-139]. More recently two study teams have reported their preliminary findings from prospective work carried out in Cote d'Ivoire. Both studies were randomised, comparing placebo with daily cotrimoxazole. One was performed in HIV-infected adults on TB therapy and the other in a general HIV-infected adult cohort. Both showed a significant effect in reducing respiratory illness $[140,141]$. The complete results of these studies are awaited but suggest that daily co-trimoxazole may be useful in controlling $S$. pneumoniae infections in Africa. However, large numbers of people receiving daily co-trimoxazole will significantly affect antimicrobial resistance patterns in all bacterial populations and there may be unforeseen public health consequences of this strategy.

\section{Conclusion}

S. pneumoniae is a ubiquitous human pathogen and will continue to be an important HIV-associated problem. Whether better HIV control in the developed world will reduce susceptibility to infection is unknown; it will certainly increase the number of individuals at risk. The failure of the 23-valent polysaccharide vaccine is a major setback, particularly in the developing world where it offered the most realistic hope of achieving control of $S$. pneumoniae infections. A better understanding of the host-bacteria interaction and newer vaccines may provide a fresh focus for prevention, but there is no immediate promise of success. The enthusiasm to promote mass chemoprophylaxis has to be tempered by the provisional nature of efficacy results, and the potential for adverse effects on public health and bacterial ecology. Consequently management in the foreseeable future will continue to rely on the knowledgeable and alert clinician.

\section{NON-TYPHOIDAL SALMONELLAE IN AIDS}

C. A. Hart*, S. Kariuki*†, S. M. Graham ${ }^{* *}$ and M. A. Gordon* ${ }^{*}$

* Department of Medical Microbiology and Genitourinary Medicine, University of Liverpool, Daulby Street, Liverpool, L69 3GA, ${ }^{\dagger}$ Kenya Medical Research Institute, Nairobi, Kenya, ${ }^{*}$ College of Medicine, University of Malawi, Blantyre, Malawi and ${ }^{\S}$ Gastroenterology and Liver Unit, Royal Hallamshire Hospital, Sheffield, S10 2JF

Salmonella enterica comprises a large number of serovars. S. enterica serovars Typhi and Paratyphi A, $\mathrm{B}$ and $\mathrm{C}$ cause typhoid and paratyphoid fevers, respectively, in which the pathogens penetrate through the intestinal mucosa, produce bacteraemia and lodge in the macrophages of the reticulo-endothelial system. The remaining c. 2200 serovars are generally considered zoonotic and are causes of diarrhoeal disease. Nevertheless, even these non-typhoidal salmonellae (NTS) can cause bacteraemia.

Even in well-nourished children in developed countries, up to $24 \%$ infected with NTS experience transient asymptomatic bacteraemia $[142,143]$. In contrast, studies in African children have shown repeatedly that NTS are the commonest cause of bacteraemia, being responsible for $40-60 \%$ of cases [144]. Here, factors predisposing to the development of NTS septicaemia include malaria, severe malarial anaemia, sickle cell disease, malnutrition and schistosomiasis [145, 146-148]. HIV infection does not appear to play a major role in susceptibility to NTS bacteraemia in African children [144, 146]. However, there is a suggestion that relapse of NTS bacteraemia after completion of appropriate antimicrobial chemotherapy is more common in HIV-infected children [147]. 
In contrast, NTS septicaemia is one of the most frequent manifestations of HIV disease in adults in Africa [98, 149-152] and elsewhere [153]. In a Kenyan study, a total of 138 NTS isolations were made from 1220 episodes of fever in adults admitted to the Kenyatta Hospital, Nairobi [150]. This represented $11.3 \%$ of all blood cultures and well over $50 \%$ of positive blood cultures. A total of 224 (19.7\%) of the 1220 patients with febrile episodes were HIV seropositive, but $95(68.8 \%)$ of the 138 with NTS bacteraemia were HIV infected, demonstrating a strong association ( $p<0.001$ ) between being HIV seropositive and having NTS bacteraemia [150]. In Malawi NTS were found to be a major cause of bacteraemia and of mortality in adults and showed an overwhelming association with HIV infection [152]. Studies in the USA have estimated that NTS bacteraemia is 100-fold more common in HIV-infected adults than in the general population [153, 154]. There are case reports of focal NTS infections in HIV, including endocarditis [155], intracranial infections [156] and pyomyositis [157]. Pulmonary involvement in HIV-infected patients with NTS bacteraemia is well recognised, and may represent either isolated NTS lung disease or co-infection with a second respiratory pathogen [158]. Despite these isolated reports, most case series find that focal metastatic NTS infections in HIV are rare [157, 159]. Presentation may mimic enteric fever [107], and a lack of diarrhoea or other gastrointestinal symptoms is commonly reported in HIV-positive patients [157, 159].

Relapse of infection is an AIDS-defining event. Between 22\% [159] and 44\% (Gordon et al. unpublished data) of patients have recurrent bacteraemia reported, in a median time of 87 days [159]. Interestingly, in a Spanish study, relapse was least likely to occur in patients receiving zidovudine and the antiviral agent was shown to be bactericidal at therapeutically achievable concentrations [159]. The role of antibiotic therapy in preventing relapses is unclear.

\section{The bacteria}

There are well over 2000 serovars of the zoonotic $S$. enterica, but Typhimurium and Enteritidis are those implicated most frequently in invasive disease in AIDS. In Kenya, $75 \%$ of the blood isolates from adults with AIDS were Typhimurium with smaller proportions of Enteritidis (9.5\%), Newport (8.4\%) and Choleraesuis (3.6\%) [150] and a similar pattern was found in Malawi [152]. However, in a recent study from Spain, $65 \%$ of the NTS blood isolates were Enteritidis and only $27 \%$ were Typhimurium [159].

In developed countries one particular phage type or clone of Typhimurium or Enteritidis tends to be responsible for most cases of salmonellosis. For example, Typhimurium definitive phage type (DT)
204C was the predominant cause of salmonellosis in man and livestock in the 1980s in the UK [160]; this has now been superseded by DT104 [161]. Enteritidis PT4 associated with poultry and their eggs is the predominant cause of human infection from these sources [162]. In contrast, in Nairobi among the Typhimurium isolates there were 11 different DTs and $31 \%$ were untypable or reacted non-specifically with phages. There was a predominance of DT 56, but this represented only $27 \%$ of the isolates [163]. However, PFGE of macrorestricted chromosomal DNA further subdivided the isolates into different genotypes. For example, there were five separate genotypes of DT 56 and four of DT 193 [163]. It does appear that invasive salmonellosis in AIDS patients in Kenya, at least, does not result from dissemination of a single clone of Typhimurium, rather multiple different clones are responsible.

\section{Antimicrobial susceptibility}

In developed countries there is great concern over the development of antimicrobial resistance among zoonotic salmonellae. For example, Typhimurium DT 104 has a multidrug resistance phenotype encoded on a chromosomal integron [164] and there has been an increase in fluoroquinolone resistance among some Salmonella serovars [165]. Resistance is also a problem in some developing countries. For example, in Nairobi between $48 \%$ and $56 \%$ of the isolates were resistant to three or more of the antimicrobial agents routinely available in Kenya for therapy [150, 163]. Overall, 48\% were resistant to ampicillin, 35\% to cefuroxime, $49 \%$ to streptomycin, $46 \%$ to co-trimoxazole, $26 \%$ to chloramphenicol and $66 \%$ to tetracycline. Resistance was transferable on $c$. $100-\mathrm{kb}$ plasmids of differing incompatibility and restriction endonuclease digest patterns [150]. Fortunately, resistance to fluoroquinolones (which are not readily available in Kenya) is rare $[150,163]$, but the current levels and extent of resistance pose considerable therapeutic problems.

\section{Bacterial pathogenicity}

Recently, it has become clear that pathogenic bacteria have acquired clusters of virulence genes called pathogenicity islands [166,167]. Pathogenicity islands (PI), have a different $\mathrm{G}+\mathrm{C}$ content from the rest of the chromosome (or plasmid in the case of Yersinia pestis or Shigella dysenteriae), are often flanked by invert repeats and are inserted close to tRNA genes, which suggests that they are of exogenous origin. Such PIs often encode type III secretion systems which are assembled and dismantled according to environmental conditions and inject molecules into eukaryotic host cells modifying their activity [167]. S. enterica has at least five PIs and a number of smaller islets [168-172]. Their functions are gradually being unravelled (Table 5); 
Table 5. Salmonella pathogenicity islands (SPI)

\begin{tabular}{|c|c|c|c|c|c|}
\hline Characteristics & SPI-1 & SPI-2 & SPI-3 & SPI-4 & SPI-5 \\
\hline $\begin{array}{l}\text { Chromosomal } \\
\text { location }\end{array}$ & $\begin{array}{l}63 \mathrm{~min} \text { (not close to } \\
\text { tRNA gene) }\end{array}$ & $\begin{array}{l}30.7 \text { min ( } v a l \mathrm{~V} \text { tRNA } \\
\text { gene) }\end{array}$ & $\begin{array}{l}82 \min (\text { selC tRNA } \\
\text { gene) }\end{array}$ & $\begin{array}{l}92 \text { min (putative } \\
\text { tRNA gene) }\end{array}$ & $\begin{array}{l}20 \text { min }(\operatorname{ser} \mathrm{T} \text { tRNA } \\
\text { gene) }\end{array}$ \\
\hline Size & $40 \mathrm{~kb}(30 \mathrm{ORF})$ & $40 \mathrm{~kb}(32 \mathrm{ORF})$ & $17 \mathrm{~kb}(10 \mathrm{ORF})$ & $25 \mathrm{~kb}$ (18 ORF) & $3.8 \mathrm{~kb}(6 \mathrm{ORF})$ \\
\hline Secretion system & $\begin{array}{l}\text { Type III and } \mathrm{ABC} \\
\text { iron transporter }\end{array}$ & Type III & $?$ & Type I & Nil \\
\hline Secreted proteins & $\begin{array}{l}\text { SipA, Spt B SopB, } \\
\text { AvrA }\end{array}$ & SpiC & MgtC & $?$ & Sop B \\
\hline Function & $\begin{array}{l}\text { Penetration into } \\
\text { enterocytes }\end{array}$ & $\begin{array}{l}\text { Invasion into tissues, } \\
\text { inhibition of phago- } \\
\text { lysosome fusion (SpiC) }\end{array}$ & $\begin{array}{l}\text { Intramacrophage } \\
\text { survival, growth at } \\
\text { low }\left[\mathrm{Mg}^{2+}\right]\end{array}$ & $\begin{array}{l}\text { Intramacrophage } \\
\text { survival? induction } \\
\text { of apoptosis }\end{array}$ & Diarrhoeal disease \\
\hline
\end{tabular}

however, it is clear that there is a degree of redundancy, i.e., some activities are encoded by more than one PI. Some are unstable (e.g., SPI-2) and some encode different genes depending on the serovar (e.g., SPI-3). Whether there are differences between NTS causing invasive disease and those causing just diarrhoeal disease is not known.

\section{Transmission, colonisation and invasion}

Although it is assumed that NTS infections are acquired as food-borne zoonoses, this might not be the case in developing countries. An extensive survey of cattle, goat, camel, pig and poultry farms and abattoirs, wild rodents, food samples and water-courses draining farms and abattoirs, has detected only a few colonised animals or contaminated food or water samples (Kariuki et al. unpublished data). When serotyped and genotyped, the NTS obtained were unrelated to those isolated from patients. Whether person-to-person transmission is a major route of transmission in developing countries is not clear.

The portal of entry is presumed to be the gastrointestinal tract either through $M$ cells or directly through enterocytes. However, it is noteworthy that not all individuals with invasive NTS infection, either children or HIV-infected adults, have concurrent diarrhoea or isolation of the bacteria from stool $[144,146,159,173]$. Thus, in a Spanish study, only $34 \%$ of AIDS patients with NTS bacteraemia had diarrhoea and salmonellae were isolated from the stools of only 4\% [159]. Pharyngeal colonisation of children by enteric bacteria, at least in developing countries, is not uncommon [174] and more frequent in those immunocompromised by malnutrition [175]. This is an area rich in lymphoid tissue that might also be a portal of entry for NTS.

From the intestine, NTS reach the bloodstream via lymphatics. In addition to invasion by penetration of $\mathrm{M}$ cells and epithelial cells, it has recently been reported that NTS can also traverse the gut mucosa and disseminate extra-intestinally to the liver and spleen via CD18-expressing phagocytes (monocyte-macrophage lineages), inside which the bacteria survive
[176]. This could conceivably facilitate reticuloendothelial persistence of NTS during antimicrobial chemotherapy, leading to relapsing infection.

Although the impressive array of virulence determinants, which also include plasmid-encoded genes ( $s p v)$ and flagella, expressed by NTS are of major importance, the immune deficit in HIV-infected patients clearly contributes to invasive disease. Interferon- $\gamma$ and interleukin-12 (IL-12) are essential for monocyte/ macrophage control of intracellular infections including NTS, and patients with congenital deficiencies in interferon- $\gamma$ or IL-12 protein or receptor components are susceptible to NTS bacteraemia $[177,178]$. IL-12 expression by peripheral blood mononuclear cells is decreased in HIV infection [179] and IL-10, which down-regulates IL-12 production, is over-expressed in HIV infection [180]. Thus, at least one of the key factors involved in diminishing the severity of NTS infection is suppressed in HIV infection. Nramp (natural resistance-associated macrophage protein) is involved in iron transport, and deficiency may be important in NTS and other intracellular infections [181]. However, as yet there is no information on Nramp expression in HIV infection.

\section{Conclusions}

There is a complex interplay of bacterial virulence mechanisms and host immunity which determines the severity of NTS disease. In adult HIV infection and in paediatric malarial anaemia, sickle cell disease and malnutrition, the balance is tilted in favour of the bacterium. Further understanding of the epidemiology of transmission and of the immune mechanisms involved in these groups will greatly increase our understanding of the pathogenesis of invasive NTS disease.

\section{DRUG INTERACTIONS IN AIDS}

P. G. Hoggard, S. Kewn and D. J. Back

Department of Pharmacology and Therapeutics, University of Liverpool, New Medical Building, Ashton Street, Liverpool. L69 $3 G E$ 
Antiretroviral treatment for HIV involves a combination of nucleoside analogue reverse transcriptase inhibitors, non-nucleoside reverse transcriptase inhibitors and protease inhibitors [182] (Table 6). However, the widespread use of other drugs (e.g., antiviral, antifungal and antimicrobial agents) administered concomitantly with antiretroviral treatment provides an enormous potential for drug-drug interactions [183].

It is beyond the capacity of this review to describe in detail all the potential drug interactions with antiretroviral agents used to treat HIV disease; therefore, it will focus on some of the major drug interactions. For those involved in prescribing for HIV positive patients we have set up a website with comprehensive drugdrug interaction charts which present an up-to-date evaluation of all potential interactions with antiretroviral treatment [184].

\section{Nucleoside reverse transcriptase inhibitors}

The six nucleoside reverse transcriptase inhibitors (NRTIs) listed in Table 6 are analogues of the host's deoxynucleosides. NRTIs have a short plasma elimination half-life and are predominantly eliminated by the kidneys $[185,186]$. Zidovudine (ZDV) is the only NRTI to undergo significant hepatic metabolism (to its glucuronide metabolite) [187]. Therefore, drugs inhibiting glucuronidation (e.g., probenecid) are likely to increase the plasma concentration of ZDV [188]. Interaction studies with other antiretroviral therapies and NRTIs have demonstrated only modest changes in the area under the plasma drug concentration-time curves (AUCs) of the NRTIs [189]. These interactions are unlikely to be clinically relevant because activity depends on the extent of intracellular phosphorylation [190].

NRTIs must be taken up into target cells and phosphorylated to their active triphosphate anabolites by intracellular enzymes [191,192]. The active 5'triphosphates (ddNTPs) compete with endogenous deoxynucleoside triphosphates (dNTPs) for incorporation into viral DNA, thus inhibiting viral DNA synthesis [193]. Phosphorylation of the NRTIs is catalysed by enzymes that are normally responsible

Table 6. Currently available antiretroviral therapies [182]

\begin{tabular}{lll}
\hline Nucleoside analogues & Protease inhibitors & $\begin{array}{l}\text { Non-nucleoside reverse } \\
\text { transcriptase inhibitors }\end{array}$ \\
\hline Zidovudine (ZDV) & Saquinavir (SQV) & Nevirapine \\
Zalcitabine (ddC) & Ritonavir (RTV) & Delavirdine \\
Didanosine (ddI) & Indinavir (IDV) & Efavirenz \\
Stavudine (d4T) & Nelfinavir (NFV) & \\
Lamivudine (3TC) & Amprenavir (APV) & \\
Abacavir (ABC) & & \\
\hline
\end{tabular}

for the formation of deoxynucleosides through the salvage pathway within the host cell (Fig. 4) [193].

Maintenance of an adequate concentration of ddNTP (and the ratio of ddNTP to endogenous dNTP) is essential for successful therapy. Relatively few interactions have been documented associated with intracellular phosphorylation. However, an important interaction occurs between the thymidine analogues zidovudine (ZDV) and stavudine (d4T) which compete for the host cell's intracellular kinases (Fig. 4). Coadministration of ZDV and $\mathrm{d} 4 \mathrm{~T}$ at equal concentrations in vitro markedly decreases $\mathrm{d} 4 \mathrm{~T}$ activation, but $\mathrm{ZDV}$ phosphorylation is unaltered [194]. This is because thymidine kinase has a 600-fold higher affinity for ZDV than d4T. The clinical effect of this interaction was seen in ACTG 290, when the ZDV plus d4T arm was discontinued after interim analysis demonstrated that subjects receiving this combination had significantly greater decreases in CD4 counts than the other arms [195].

The two cytidine analogues also compete for activating enzymes (Fig. 4). Zalcitabine (ddC) inhibits lamivudine (3TC) phosphorylation in vitro at higher concentrations than observed in vivo, but ddC activation is reduced by 3TC at similar concentration ratios to those seen in patients $[196,197]$.

Modulation of NRTI phosphorylation is now a realistic therapeutic strategy. Hydroxyurea inhibits ribonucleotide reductase, which results in decreased endogenous dNTPs [198], an increase in the ddNTP/dNTP ratio and thus anti-HIV activity. Clinical benefit has been demonstrated clinically when hydroxyurea was combined with didanosine [199]. It is clearly important to measure both ddNTP and dNTP in intracellular pharmacokinetic studies. A knowledge of the mechanism of action of NRTI may allow clinical benefit from drug interactions.

Drug interactions involving ddI occur as a consequence of the neutralising agents in oral preparations of the drug. Therefore, it is recommended that ddI is administered $1 \mathrm{~h}$ apart from drugs requiring an acidic environment for optimal absorption (e.g., indinavir) [200].

\section{Protease inhibitors}

Protease inhibitors are extensively metabolised by enterocyte and hepatic cytochrome P450 (CYP) enzymes [201]. The iso-enzyme largely responsible for metabolism of the protease inhibitors is cytochrome P450 3A4, with CYP2C9 and CYP2D6 also contributing [189]. In addition to being metabolised by this enzyme, each protease inhibitor can induce or inhibit CYP3A and other CYP enzymes, or both. This results in a complex set of drug interactions (Table 7). 

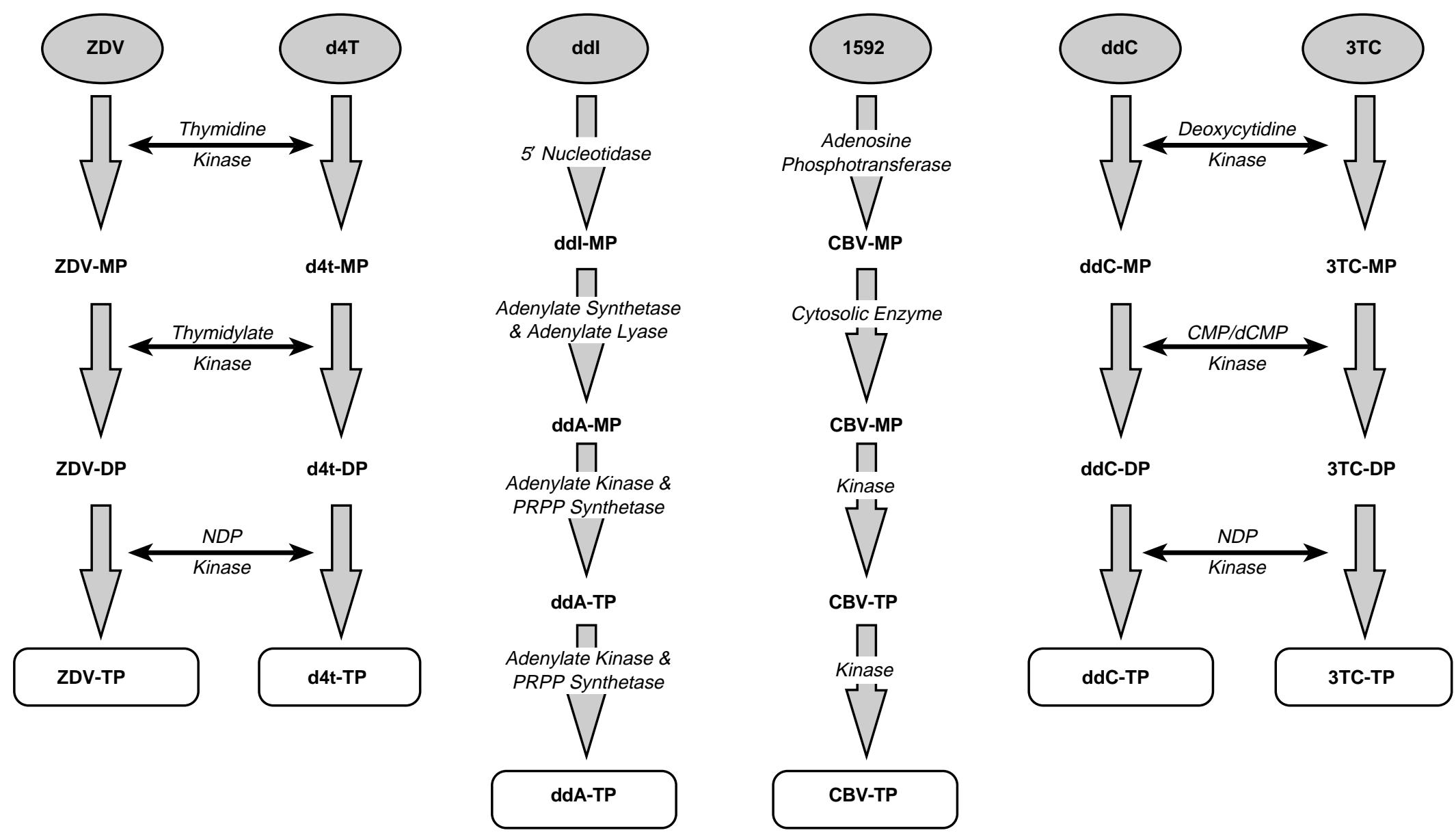

Fig. 4. Activation of the nucleoside analogues:1592, abacavir; CBV, carbovir. 
Table 7. Summary of the pharmacokinetic interactions between protease inhibitors and non-nucleoside reverse transcriptase inhibitors

\begin{tabular}{|c|c|c|c|c|c|}
\hline \multirow[b]{2}{*}{ Affecting drugs } & \multicolumn{5}{|c|}{ Affected drugs } \\
\hline & Indinavir & Ritonavir & Saquinavir (soft gel) & Nelfinavir & Amprenavir \\
\hline Indinavir & & No interaction & $\uparrow 600 \%$ & $\uparrow 84 \%$ & $\uparrow 64 \%$ \\
\hline Ritonavir & $\uparrow 500 \%$ & $\ldots$ & $\uparrow 2000 \%$ & $\uparrow 250 \%$ & No data \\
\hline Saquinavir & No data & No interaction & $\ldots$ & $\uparrow 17 \%$ & $\downarrow 36 \%$ \\
\hline Nelfinavir & $\uparrow 51 \%$ & No interaction & $\uparrow 500 \%$ & $\ldots$ & $\uparrow \mathrm{C}_{\min } 167 \%$ \\
\hline Amprenavir & $\downarrow 38 \%$ & No data & $\downarrow 18 \%$ & $\uparrow 15 \%$ & $\ldots$ \\
\hline Nevirapine & $\downarrow 28 \%$ & $\downarrow 10 \%$ & $\downarrow 27 \%$ & No interaction & No data \\
\hline Delavirdine & $\uparrow \mathrm{C}_{\max } 2-500 \%$ & $\uparrow 70 \%$ & $\uparrow 500 \%$ & $\uparrow 90 \%$ & No data \\
\hline Efavirenz & $\downarrow \mathrm{C}_{\max } 35 \%$ & $\uparrow 17 \%$ & No data & $\uparrow 15 \%$ & $\downarrow 36 \%$ \\
\hline
\end{tabular}

Interactions are expressed as a percentage change in the area under the concentration-time curve (AUC) unless stated.

$\mathrm{C}_{\max }$ and $\mathrm{C}_{\min }$, maximum and minimum plasma concentration; $\uparrow$ and $\downarrow$, increase and decrease (for references see text).

\section{Saquinavir $(S Q V)$}

The poor systemic availability of SQV (hard gel capsule c. $4 \%$; soft gel capsule c. $12 \%$ ) is a consequence of rapid and extensive metabolism $[202,203]$. SQV is metabolised by CYP3A4 and so has the potential to interact with drugs that either induce or inhibit this enzyme [201]. Induction of SQV is particularly important as many patients are believed to have SQV plasma levels near or below the minimum effective concentrations [204]. Co-administration of inducers of CYP 3A4 increase metabolism resulting in decreases in steady-state AUC and peak plasma concentration $\left(\mathrm{C}_{\max }\right)$ of SQV. In contrast, drugs that inhibit CYP3A4 may increase plasma concentrations of SQV, increasing the AUC of SQV.

Ritonavir is a potent inhibitor of CYP3A4 and coadministration of RTV and SQV results in increases in the $C_{\max }$ and AUC of SQV [205, 206]. The AUCs of the hard and soft gel formulations of SQV have been shown to increase in the presence of RTV $>50$-fold and 20-fold respectively [206, 207]. Similarly, the protease inhibitors nelfinavir and indinavir inhibit CYP3A4, increasing mean plasma concentrations and AUCs of SQV during co-administration. Indinavir and nelfinavir increased the AUC of soft gel SQV by sixfold and five-fold respectively [207, 208]. These interactions are of clinical benefit, as increased bioavailability results in enhanced antiviral activity and, perhaps, dose reduction.

The non-nucleoside nevirapine is an inducer of CYP3A4 enzymes and has been shown to reduce the AUC of hard gel SQV by $27 \%$ [209, 210]. However, administration of hard gel SQV with the CYP3A inhibitor, delavirdine, results in a five-fold increase in the AUC of SQV [211]. Drugs used to treat opportunist infections such as clarithromycin, erythromycin, fluconazole and ketoconazole also inhibit CYP3A4 [207]. Concomitant administration of SQV (soft gel) with clarithromycin resulted in increases in mean SQV $\mathrm{C}_{\max }$ and AUC of 187 and 177\%, respectively [207].
SQV itself is a weak inhibitor of CYP3A4 and increases the plasma concentrations of drugs also metabolised by this isozyme [212]. However, SQV is the least potent inhibitor of CYP3A4 and has little effect on the pharmacokinetics of the other protease inhibitors (Table 7). Co-administration of SQV and terfenadine resulted in increases in terfenadine $\mathrm{C}_{\max }$ (253\%) and AUC (368\%) [213]. The resulting risk of serious cardiac arrhythmias means that these drugs should not be given together.

The role of P-glycoprotein is also a possible mechanism for drug interactions. P-glycoprotein is a transmembrane protein capable of actively transporting drugs out of intestinal, hepatic and renal cells, thus increasing cellular clearance [214]. P-glycoprotein and CYP3A metabolism have overlapping substrate specificities and SQV has been shown to be a substrate for Pglycoprotein [215]. Drug interactions may be anticipated with either substrates or inhibitors of Pglycoprotein (e.g., ketoconazole) [216].

\section{Ritonavir (RTV)}

RTV is a potent inhibitor of CYP3A4 and to a lesser extent CYP2D6 and CYP2C9 [205]. RTV increases the plasma concentration of agents metabolised by CYP3A4 but to a greater extent than SQV. Giving a combination of RTV and IDV to healthy volunteers resulted in increases in the $\mathrm{AUC}(480 \%)$ and $\mathrm{C}_{\max }$ $(110 \%)$ of IDV [217]. Similarly, co-administration of NFV and RTV produced a $152 \%$ increase in the $\mathrm{AUC}_{0-8 \mathrm{~h}}$ of NFV [218]. However, the plasma concentration of RTV is unaltered with IDV, NFV and SQV $[217,219,220]$.

The potent inhibitory effect of RTV on CYP3A4 activity means that concomitant use with astimazole, terfenadine and cisapride is likely to be associated with cardiac arrhythmias [221]. Concurrent use of RTV with a number of anti-arrhythmics and sedatives is contraindicated. 
RTV enhances the bioavailability of drugs metabolised by CYP3A [221]. Agents metabolised by other CYP450s may have reduced bioavailability. Inducers of CYP3A4 are likely to lead to sub-therapeutic levels of RTV and should be avoided. RTV induces its own metabolism and also induces the metabolism of some other drugs.

\section{Indinavir (IDV)}

Inhibition of CYP3A4 by IDV leads to interactions with substrates of this enzyme [222]. Also, addition of an inhibitor of CYP3A4 to an IDV regimen leads to an increase in IDV concentrations. On the other hand, patients treated with inducers of this enzyme, such as phenobarbital or rifabutin, result in decreased IDV concentrations [204].

Drug interactions with dual PI therapy are often beneficial. A study that used lower dose RTV (100 $\mathrm{mg}$ ) in combination with higher doses of IDV showed enhanced IDV concentrations with increased trough and decreased peak levels [223]. This may reduce toxicity whilst sustaining efficacy.

The non-nucleoside reverse transcriptase inhibitors nevirapine and efavirenz are enzyme inducers [224]. Both nevirapine and efavirenz decreased IDV levels by c. $30 \%$. In contrast, delavirdine is an inhibitor of CYP3A4 and has been shown to increase the AUC of indinavir [211].

Co-administration of IDV and nelfinavir in healthy volunteers resulted in increases in the AUC of both IDV $(51 \%)$ and nelfinavir $(84 \%)$. Similar AUC increases in both IDV (38\%) and amprenavir (64\%) were seen in HIV patients [225].

\section{Nelfinavir (NFV)}

NFV has potential to impair drug metabolism, but drug interactions are further complicated by the fact that NFV has an active metabolite (AG-1402) [226,227]. In one study delavirdine increased the AUC of nelfinavir by $90 \%$ but decreased AG-1402 by $44 \%$, thereby prolonging the overall elimination half-life [228].

\section{Amprenavir (APV)}

APV has been shown to inhibit CYP3A4 and CYP2C9 with inhibition of 3A4 similar to NFV and IDV [229]. Interactions between APV and SQV or NFV are modest and unlikely to be clinically significant [229]. Coadministration of APV (1200 mg) with ketoconazole (400 mg) resulted in c. $40 \%$ increases in the AUCs of both agents. Clinically significant interactions have been demonstrated with rifabutin and rifampicin and it is recommended that APV should not be administered with rifampicin [229]. Induction by the non-nucleoside reverse transcriptase inhibitor, efavirenz, results in a
$36 \%$ decrease in the AUC of amprenavir when these two drugs are administered [230].

\section{Non-nucleoside reverse transcriptase inhibitors}

The non-nucleoside reverse transcriptase inhibitors currently available - nevirapine, delavirdine and efavirenz - undergo extensive metabolism [209]. Drug-drug interactions are anticipated when these drugs are administered with protease inhibitors or if two non-nucleoside reverse transcriptase inhibitors are prescribed.

Nevirapine is an inducer of cytochrome P450 enzymes which reduces the AUCs of the protease inhibitors. Nevirapine also reduced the clarithromycin AUC by $30 \%$. However, the antibacterial active metabolite 14$\mathrm{OH}$ clarithromycin was increased, probably due to induction of CYP450 metabolism by nevirapine [231].

NFV decreased delavirdine AUC (42\%) in healthy volunteers, but no data are available for HIV patients [228]. None of the other protease inhibitors studied (SQV, RTV and IDV) have shown any effect on delavirdine metabolism [232-234]. Surprisingly, delavirdine concentrations decrease in the presence of adefovir. Delavirdine is metabolised in the liver whereas adefovir is excreted renally. The reason for the interaction in this small study is unknown but may be an effect of adefovir on the P-glycoprotein drug transporter.

Co-administration of didanosine and delavirdine produced a decrease in the AUC of delavirdine (38\%) compared with the AUC when administration of the two drugs was separated by $1 \mathrm{~h}$ [235]. This is the only reported drug-drug interaction between nucleoside analogue and non-nucleoside analogue reverse transcriptase inhibitors.

The induction effect of efavirenz is not as predictable as with nevirapine. Combination of nelfinavir and efavirenz in healthy volunteers resulted in an inhibitory effect with an increase in the AUC by $20 \%$ and a decrease in the AUC of its metabolite AG-1402 by $37 \%$ [236]. The only protease inhibitor to alter the pharmacokinetics of efavirenz was ritonavir, which increased the plasma concentration of efavirenz by $21 \%$, but this is unlikely to require dose modification [237].

\section{Conclusion}

This review demonstrates that drug reactions may compromise therapeutic efficacy or increase toxicity. However, some of the interactions between two-drug combinations of protease inhibitors are beneficial. It is essential that clinicians have a full understanding of 
drug interactions when prescribing to HIV patients. A comprehensive updated summary of the possible drug interactions encountered with antiretroviral therapy is available through the internet [184].

\section{References}

1. Centers for Disease Control. Kaposi's sarcoma and Pneumocystis pneumonia among homosexual men - New York City and California. MMWR Morb Mortal Wkly Rep 1981; 30: 305-308.

2. Keersmaekers K, Meheus A. Epidemiology of sexually transmitted infections and AIDS in developing countries. In: Arya OP, Hart CA (eds) Sexually transmitted infections and AIDS in the tropics. Wallingford, Oxon, CABI Publishing. 1998: 3-30.

3. Morgan D, Maude GH, Malamba SS et al. HIV-1 disease progression in AIDS-defining disorders in rural Uganda. Lancet 1997; 350: 245-250.

4. Graham SM, Mtitimila EI, Kamanga HS, Walsh AL, Hart CA, Molyneux ME. Clinical presentation and outcome of Pneumocystis carinii pneumonia in Malawian children. Lancet 2000; 355: 369-373.

5. Lucas SB, Peacock CS, Hounnou A et al. Disease in children infected with HIV in Abidjan, Côte d'Ivoire. BMJ 1996; 312: 335-338.

6. Palella FJ, Delaney KM, Moorman AC et al. Declining morbidity and mortality among patients with advanced human immunodeficiency virus infection. $N$ Engl J Med 1998; 338: $853-860$.

7. Mocroft A, Vella S, Benfield TL et al. Changing patterns of mortality across Europe in patients infected with HIV-1. Lancet 1998; 352: 1725-1730.

8. Kline MW, Fletcher CV, Harris AT et al. A pilot study of combination therapy with indinavir, stavudine (d4T), and didanosine (ddI) in children infected with human immunodeficiency virus. J Pediatr 1998; 132: 543-546.

9. Wintergerst U, Hoffmann F, Sölder B et al. Comparison of two antiretroviral triple combinations including the protease inhibitor indinavir in children infected with human immunodeficiency virus. Pediatr Infect Dis J 1998; 17: 495-499.

10. Luzuriaga $\mathrm{K}$, Bryson $\mathrm{Y}$, Krogstad $\mathrm{P}$ et al. Combination treatment with zidovudine, didanosine, and nevirapine in infants with human immunodeficiency virus type 1 infection. $N$ Engl J Med 1997; 336: 1343-1349.

11. Starr SE, Fletcher CV, Spector SA et al. Combination therapy with efavirenz, nelfinavir, and nucleoside reverse-transcriptase inhibitors in children infected with human immunodeficiency virus type 1. $N$ Engl J Med 1999; 341: 1874-1881.

12. Wei X, Ghosh SK, Taylor ME et al. Viral dynamics in human immunodeficiency virus type 1 infection. Nature 1995; 373: $117-122$.

13. Ho DD, Neumann AU, Perelson AS, Chen W, Leonard JM, Markowitz M. Rapid turnover of plasma virions and CD4 lymphocytes in HIV-1 infection. Nature 1995; 373: 123-126.

14. Larder BA, Kemp SD. Multiple mutations in HIV-1 reverse transcriptase confer high-level resistance to Zidovudine (AZT). Science 1989; 246: 1155-1158.

15. Boden D, Hurley A, Zhang L et al. HIV-1 drug resistance in newly infected individuals. JAMA 1999; 282: 1135-1141.

16. Schneider MME, Borleffs JCC, Stolk RP, Jaspers CAJJ, Hoepelman AIM. Discontinuation of prophylaxis of Pneumocystis carinii pneumonia in HIV-1-infected patients treated with highly active antiretroviral therapy. Lancet 1999; 353: 201-203.

17. Furtado MR, Callaway DS, Phair JP et al. Persistence of HIV1 transcription in peripheral-blood mononuclear cells in patients receiving potent antiretroviral therapy. $N$ Engl $J$ Med 1999; 340: 1614-1622.

18. Zhang $\mathrm{H}$, Dornadula $\mathrm{G}$, Beumont $\mathrm{M}$ et al. Human immunodeficiency virus type 1 in the semen of men receiving highly active antiretroviral therapy. $N$ Engl J Med 1998; 339: 1803-1809.

19. Zhang L, Ramratnam B, Tenner-Racz K et al. Quantifying residual HIV-1 replication in patients receiving combination antiretroviral therapy. $N$ Engl J Med 1999; 340: 1605-1613.
20. Feinberg M. Hidden dangers of incompletely suppressive antiretroviral therapy. Lancet 1997; 349: 1408-1409.

21. Hirsch MS, Conway B, D'Aquila RT et al. Antiretroviral drug resistance testing in adults with HIV infection: implications for clinical management. International AIDS Society - USA Panel. JAMA 1998; 279: 1984-1991.

22. Durant J, Clevenbergh $\mathrm{P}$, Halfon $\mathrm{P}$ et al. Drug resistance genotyping in HIV-1 therapy: the VIRADAPT randomised controlled trial. Lancet 1999; 353: 2195-2199.

23. Ledergerber $\mathrm{B}$, Egger $\mathrm{M}$, Opravil $\mathrm{M}$ et al. Clinical progression and virological failure on highly active antiretroviral therapy in HIV-1 patients: a prospective cohort study. Swiss HIV Cohort Study. Lancet 1999; 353: 863-868.

24. Canning EU. Microsporidia. In: Kreier JP (ed) Parasitic protozoa, 2nd edn, vol 6. San Diego, Academic Press. 1993: 299-370.

25. Canning EU, Lom J. Dýková I. The microsporidia of vertebrates. London, Academic Press.1986.

26. van Gool T, Vetter JCM, Weinmayr B, Van Dam A, Derouin F, Dankert J. High seroprevalence of Encephalitozoon species in immunocompetent subjects. J Infect Dis 1997; 175: 10201024.

27. Desportes I, Le Charpentier Y, Galian A et al. Occurrence of a new microsporidian: Enterocytozoon bieneusi n. g., n. sp., in the enterocytes of a human patient with AIDS. J Protozool 1985; 32: $250-254$

28. Asmuth DM, DeGirolami PC, Federman M et al. Clinical features of microsporidiosis in patients with AIDS. Clin Infect Dis 1994; 18: 819-825.

29. Cali A, Kotler DP, Orenstein JM. Septata intestinalis N.G. N.Sp., an intestinal microsporidian associated with chronic diarrhea and dissemination in AIDS patients. $J$ Eukaryot Microbiol 1993; 40: 101-112.

30. Blanshard C, Hollister WS, Peacock CS et al. Simultaneous infection with two types of intestinal microsporidia in a patient with AIDS. Gut 1992; 33: 418-420.

31. Weber R, Bryan RT, Schwartz DA, Owen RL. Human microsporidial infections. Clin Microbiol Rev 1994; 7: 426461.

32. del Aguila C, Lopez-Velez R, Fenoy S et al. Identification of Enterocytozoon bieneusi spores in respiratory samples from an AIDS patient with a 2-year history of intestinal microsporidiosis. J Clin Microbiol 1997; 35: 1862-1866.

33. Eeftinck Schattenkerk JKM, van Gool T, van Ketel RJ et al. Clinical significance of small-intestinal microsporidiosis in HIV-1-infected individuals. Lancet 1991; 337: 895-898.

34. Kyaw T, Curry A, Edwards-Jones V, Craske J, Mandal BK. The prevalence of Enterocytozoon bieneusi in acquired immunodeficiency syndrome (AIDS) patients from the north west of England: 1992-1995. Br J Biomed Sci 1997; 54: 186-191.

35. Rabeneck L, Gyorkey F, Genta RM, Gyorkey P, Foote LW, Risser JMH. The role of microsporidia in the pathogenesis of HIV-related chronic diarrhea. Ann Intern Med 1993; 119: 895-899.

36. Didier ES, Didier PJ, Friedberg DN et al. Isolation and characterization of a new microsporidian, Encephalitozoon hellem (n. sp.), from three AIDS patients with keratoconjunctivitis. J Infect Dis 1991; 163: 617-621.

37. Metcalfe TW, Doran RML, Rowlands PL, Curry A, Lacey CJN. Microsporidial keratoconjunctivitis in a patient with AIDS. Br J Ophthalmol 1992; 76: 177-178.

38. Schwartz DA, Visvesvara GS, Leitch GJ et al. Pathology of symptomatic microsporidial (Encephalitozoon hellem) bronchiolitis in the acquired immunodeficiency syndrome: a new respiratory pathogen diagnosed from lung biopsy, bronchoalveolar lavage, sputum, and tissue culture. Hum Pathol 1993; 24: $937-943$.

39. Curry A, Canning EU. Human microsporidiosis. J Infect 1993; 27: 229-236

40. Silveira H, Canning EU. Vittaforma corneae n. comb. for the human microsporidium Nosema corneum Shadduck, Meccoli, Davis \& Font, 1990, based on its ultrastructure in the liver of experimentally infected athymic mice. J Eukaryot Microbiol 1995; 42: 158-165.

41. Shadduck JA, Meccoli RA, Davis R, Font RL. Isolation of a microsporidian from a human patient. J Infect Dis 1990; 162: $773-776$.

42. Silveira H, Canning EU, Shadduck JA. Experimental infection 
of athymic mice with the human microsporidian Nosema corneum. Parasitology 1993; 107: 489-496.

43. Deplazes $\mathrm{P}$, Mathis A, van Saanen $\mathrm{M}$ et al. Dual microsporidian infection due to Vittaforma corneae and Encephalitozoon hellem in a patient with AIDS. Clin Infect Dis 1998; 27: 1521-1524.

44. Chupp GL, Alroy J, Adelman LS, Breen JC, Skolnik PR. Myositis due to Pleistophora (microsporidia) in a patient with AIDS. Clin Infect Dis 1993; 16: 15-21.

45. Ledford DK, Overman MD, Gonzalvo A, Cali A, Mester SW, Lockey RF. Microsporidiosis myositis in a patient with the acquired immunodeficiency syndrome. Ann Intern Med 1985; 102: $628-630$.

46. Field AS, Marriott DJ, Milliken ST et al. Myositis associated with a newly described microsporidian, Trachipleistophora hominis, in a patient with AIDS. J Clin Microbiol 1996; 34: 2803-2811.

47. Hollister WS, Canning EU, Weidner E, Field AS, Kench J, Marriott DJ. Development and ultrastructure of Trachipleistophora hominis n.g., n.sp. after in vitro isolation from an AIDS patient and inoculation into athymic mice. Parasitology 1996; 112: $143-154$.

48. Cali A, Takvorian PM, Lewin S et al. Brachiola vesicularum, n. g., n. sp., a new microsporidian associated with AIDS and myositis. J Eukaryot Microbiol 1998; 45: 240-251.

49. Vavra J, Yachnis AT, Shadduck JA, Orenstein JM. Microsporidia of the genus Trachipleistophora - causative agents of human microsporidiosis: description of Trachipleistophora anthropophthera N. Sp. (Protozoa: Microsporidia). J Eukaryot Microbiol 1998; 45: 273-283.

50. Schwartz DA, Sobottka I, Leitch GJ, Cali A, Visvesvara GS. Pathology of microsporidiosis: emerging parasitic infections in patients with acquired immunodeficiency syndrome. Arch Pathol Lab Med 1996; 120: 173-188.

51. Doultree JC, Maerz AL, Ryan NJ et al. In vitro growth of the microsporidian Septata intestinalis from an AIDS patient with disseminated illness. J Clin Microbiol 1995; 33: 463470 .

52. Schmidt EC, Shadduck JA. Murine encephalitozoonosis model for studying the host-parasite relationship of a chronic infection. Infect Immun 1983; 40: 936-942.

53. Schwartz DA, Bryan RT, Hewan-Lowe KO et al. Disseminated microsporidiosis (Encephalitozoon hellem) and acquired immunodeficiency syndrome. Autopsy evidence for respiratory acquisition. Arch Pathol Lab Med 1992; 116: 660-668.

54. Didier ES, Visvesvara GS, Baker MD et al. A microsporidian isolated from an AIDS patient corresponds to Encephalitozoon cuniculi III, originally isolated from domestic dogs. $J$ Clin Microbiol 1996; 34: 2835-2837.

55. Black SS, Steinohrt LA, Bertucci DC, Rogers LB, Didier ES. Encephalitozoon hellem in budgerigars (Melopsittacus undulatus). Vet Pathol 1997; 34: 189-198.

56. Pulparampil N, Graham D, Phalen D, Snowden K. Encephalitozoon hellem in two Eclectus Parrots (Eclectus roratus): identification from archival tissues. J Eukaryot Microbiol 1998; 45: 651-655.

57. Deplazes P, Mathis A, Baumgartner R, Tanner I, Weber R. Immunologic and molecular characteristics of Encephalitozoon-like microsporidia isolated from humans and rabbits indicate that Encephalitozoon cuniculi is a zoonotic parasite. Clin Infect Dis 1996; 22: 557-559.

58. Franzen C, Küppers R, Müller A et al. Genetic evidence for latent Septata intestinalis infection in human immunodeficiency virus-infected patients with intestinal microsporidiosis. J Infect Dis 1996; 173: 1038-1040.

59. Bornay-Llinares FJ, da Silva AJ, Moura $\mathrm{H}$ et al. Immunologic, microscopic, and molecular evidence of Encephalitozoon intestinalis (Septata intestinalis) infection in mammals other than humans. J Infect Dis 1998; 178: 820-826.

60. Deplazes P, Mathis A, Muller C, Weber R. Molecular epidemiology of Encephalitozoon cuniculi and first detection of Enterocytozoon bieneusi in faecal samples of pigs. $J$ Eukaryot Microbiol 1996; 43: 93S.

61. Mansfield KG, Carville A, Hebert D et al. Localization of persistent Enterocytozoon bieneusi infection in normal rhesus macaques (Macaca mulatta) to the hepatobiliary tree. J Clin Microbiol 1998; 36: 2336-2338.

62. Liguory O, David F, Sarfati C, Derouin F, Molina J-M. Determination of types of Enterocytozoon bieneusi strains isolated from patients with intestinal microsporidiosis. J Clin Microbiol 1998; 36: 1882-1885.

63. Trammer T, Dombrowski F, Doehring M, Maier WA, Seitz HM. Opportunistic properties of Nosema algerae (Microspora), a mosquito parasite, in immunocompromised mice. $J$ Eukaryot Microbiol 1997; 44: 258-262.

64. Vavra J, Dahbiova R, Hollister WS, Canning EU. Staining of microsporidian spores by optical brighteners with remarks on the use of brighteners for the diagnosis of AIDS associated human microsporidioses. Folia Parasitol 1993; 40: 267-272.

65. Weber R, Bryan RT, Owen RL et al. Improved lightmicroscopical detection of microsporidia spores in stool and duodenal aspirates. $N$ Engl J Med 1992; 326: 161-166.

66. Chioralia G, Trammer T, Kampen H, Seitz HM. Relevant criteria for detecting microsporidia in stool specimens. J Clin Microbiol 1998; 36: 2279-2283.

67. Enriquez FJ, Ditrich O, Palting JD, Smith K. Simple diagnosis of Encephalitozoon $s p$. microsporidial infections by using a panspecific antiexospore monoclonal antibody. J Clin Microbiol 1997; 35: 724-729.

68. Desportes-Livage I. Human microsporidioses. Curr Opin Infect Dis 1998; 11: 177-181.

69. Blanshard C, Ellis DS, Tovey DG, Dowell S, Gazzard BG Treatment of intestinal microsporidiosis with albendazole in patients with AIDS. AIDS 1992; 6: 311-313.

70. Molina J-M, Oksenhendler E, Beauvais B et al. Disseminated microsporidiosis due to Septata intestinalis in patients with AIDS: clinical features and response to albendazole therapy. $J$ Infect Dis 1995; 171: 245-249.

71. Molina J-M, Chastang C, Goguel J et al. Albendazole for treatment and prophylaxis of microsporidiosis due to Encephalitozoon intestinalis in patients with AIDS: a randomized double-blind controlled trial. J Infect Dis 1998; 177: $1373-1377$.

72. Colbourn NI, Hollister WS, Curry A, Canning EU. Activity of albendazole against Encephalitozoon cuniculi in vitro. Eur J Protistol 1994; 30: 211-220.

73. De Groote MA, Visvesvara G, Wilson ML et al. Polymerase chain reaction and culture confirmation of disseminated Encephalitozoon cuniculi in a patient with AIDS: successful therapy with albendazole. J Infect Dis 1995; 171: 1375-1378.

74. Didier ES. Effects of albendazole, fumagillin, and TNP-470 on microsporidial replication in vitro. Antimicrob Agents Chemother 1997; 41: 1541-1546.

75. Diesenhouse MC, Wilson LA, Corrent GF, Visvesvara GS, Grossniklaus HE, Bryan RT. Treatment of microsporidial keratoconjunctivitis with topical fumagillin. Am J Opthalmol 1993; 115: 293-298

76. Molina J-M, Goguel J, Sarfati C et al. Potential efficacy of fumagillin in intestinal microsporidiosis due to Enterocytozoon bieneusi in patients with HIV infection: results of a drug screening study. The French Microsporidiosis Study Group. AIDS 1997; 11:1603-1610.

77. Coyle C, Kent M, Tanowitz HB, Wittner M, Weiss LM. TNP470 is an effective antimicrosporidial agent. J Infect Dis 1998; 177: 515-518.

78. Sharpstone D, Rowbottom A, Francis N et al. Thalidomide: a novel therapy for microsporidiosis. Gastroenterology 1997; 112: $1823-1829$

79. Montaner JSG, Hogg R, Raboud J, Harrigan R, O’Shaughnessy M. Antiretroviral treatment in 1998. Lancet 1998; 352 1919-1922.

80. Goguel J, Katlama C, Sarfati C, Maslo C, Leport C, Molina $\mathrm{J}-\mathrm{M}$. Remission of AIDS-associated intestinal microsporidiosis with highly active antiretroviral therapy. AIDS 1997; 11: 1658-1659.

81. Rabodonirina M, Bertocchi M, Desportes-Livage I et al. Enterocytozoon bieneusi as a cause of chronic diarrhea in a heart-lung transplant recipient who was seronegative for human immunodeficiency virus. Clin Infect Dis 1996; 23: $114-117$.

82. Sax PE, Rich JD, Pieciak WS, Trnka YM. Intestinal microsporidiosis occurring in a liver transplant recipient. Transplantation 1995; 60: 617-618.

83. Wanke CA, DeGirolami P, Federman M Enterocytozoon bieneusi infection and diarrheal disease in patients who were not infected with human immunodeficiency virus: case report and review. Clin Infect Dis 1996; 23: 816-818.

84. Sandfort J, Hannemann A, Gelderblom H, Stark K, Owen RL, 
Ruf B. Enterocytozoon bieneusi infection in an immunocompetent patient who had acute diarrhea and who was not infected with the human immunodeficiency virus. Clin Infect Dis 1994; 19: 514-516.

85. Sobottka I, Albrecht H, Schottelius J et al. Self-limited traveller's diarrhea due to a dual infection with Enterocytozoon bieneusi and Cryptosporidium parvum in an immunocompetent HIV-negative child. Eur J Clin Microbiol Infect Dis 1995; 14: 919-920.

86. Raynaud L, Delbac F, Broussolle V et al. Identification of Encephalitozoon intestinalis in travelers with chronic diarrhea by specific PCR amplification. J Clin Microbiol 1998; 36: 37-40.

87. Witt DJ, Craven DE, McCabe WR. Bacterial infections in adult patients with the acquired immune deficiency syndrome (AIDS) and AIDS-related complex. Am J Med 1987; 82: 900-906.

88. Stoneburner RL, Des Jarlais DC, Benezra D et al. A larger spectrum of severe HIV-1-related disease in intravenous drug users in New York City. Science 1988; 242: 916-919.

89. Markowitz GS, Concepcion L, Factor SM, Borczuk AC. Autopsy patterns of disease among subgroups of an inner-city Bronx AIDS population. J Acquir Immune Defic Syndr Hum Retrovirol 1996; 13: 48-54.

90. Selwyn PA, Feingold AR, Hartel D et al. Increased risk of bacterial pneumonia in HIV-infected intravenous drug users without AIDS. AIDS 1988; 2: 267-272.

91. Barat LM, Gunn JE, Steger KA, Perkins CJ, Craven DE. Causes of fever in patients infected with human immunodeficiency virus who were admitted to Boston City Hospital. Clin Infect Dis 1996; 23: 320-328.

92. Krumholz HM, Sande MA, Lo B. Community-acquired bacteremia in patients with acquired immunodeficiency syndrome: Clinical presentation, bacteriology, and outcome. Am J Med 1989; 86: 776-779.

93. Chan IS, Neaton JD, Saravolatz LD, Crane LR, Osterberger J. Frequencies of opportunistic diseases prior to death among HIV-infected persons. Community programs for clinical research on AIDS. AIDS 1995; 9: 1145-1151.

94. Hirschtick RE, Glassroth J, Jordan MC et al. Bacterial pneumonia in persons infected with the human immunodeficiency virus. $N$ Engl $J$ Med 1995; 333: 845-851.

95. Mundy LM, Auwaerter PG, Oldach D et al. Communityacquired pneumonia: impact of immune status. Am J Respir Crit Care Med 1995; 152: 1309-1315.

96. Polsky B, Gold JWM, Whimbey E et al. Bacterial pneumonia in patients with the acquired immunodeficiency syndrome. Ann Intern Med 1986; 104: 38-41.

97. Wallace JM, Rao AV, Glassroth J et al. Respiratory illness in persons with Human Immunodeficiency Virus infection. Am Rev Respir Dis 1993; 148: 1523-1529.

98. Gilks CF, Brindle RJ, Otieno LS et al. Life-threatening bacteraemia in HIV-1 seropositive adults admitted to hospital in Nairobi, Kenya. Lancet 1990; 336: 545-549.

99. Gilks CF, Ojoo SA, Ojoo JC et al. Invasive pneumococcal disease in a cohort of predominantly HIV-1 infected female sex-workers in Nairobi, Kenya. Lancet 1996; 347: 718-723.

100. Aderaye G. Community acquired pneumonia in adults in Addis Ababa: etiologic agents and the impact of HIV infection. Tuber Lung Dis 1994; 75: 308-312.

101. Grant AD, Djomand G, Smets P et al. Profound immunosuppression across the spectrum of opportunistic disease among hospitalized HIV-infected adults in Abidjan, Cote d'Ivoire. AIDS 1997; 11: 1357-1364.

102. Jones N, Huebner R, Khoosal M, Crewe-Brown H, Klugman $\mathrm{K}$. The impact of HIV on Streptococcus pneumoniae bacteraemia in a South African population. AIDS 1998; 12: 2177-2184

103. Rubin JS, Honigberg R. Sinusitis in patients with the acquired immunodeficiency syndrome. Ear Nose Throat $J$ 1990; 69: 460-463.

104. Verghese A, al-Samman M, Nabhan D, Naylor AD, Rivera M Bacterial bronchitis and bronchiectasis in human immunodeficiency virus infection. Arch Intern Med 1994; 154: 20862091.

105. Boschini A, Smacchia C, Di Fine M et al. Communityacquired pneumonia in a cohort of former injection drug users with and without human immunodeficiency virus infection: incidence, etiologies, and clinical aspects. Clin
Infect Dis 1996; 23: 107-113.

106. Mientjes GH, van Ameijden EJ, van den Hoek JAR, Coutinho RA. Increasing morbidity without rise in non-AIDS mortality among HIV-infected intravenous drug users in Amsterdam. AIDS 1992; 6: 207-212.

107. Gilks CF, Otieno LS, Brindle RJ et al. The presentation and outcome of HIV-related disease in Nairobi. $Q J$ Med 1992; 82: $25-32$.

108. Burack JH, Hahn JA, Saint-Maurice D, Jacobson MA. Microbiology of community-acquired bacterial pneumonia in persons with and at risk for human immunodeficiency virus type 1 infection. Implications for rational empiric antibiotic therapy. Arch Intern Med 1994; 154: 2589-2596.

109. Tumbarello M, Tacconelli E, de Gaetano $\mathrm{K}$ et al. Bacterial pneumonia in HIV-infected patients: analysis of risk factors and prognostic indicators. J Acquir Immune Defic Syndr Hum Retrovirol 1998; 18: 39-45.

110. Redd SC, Rutherford GW, Sande MA et al. The role of human immunodeficiency virus infection in pneumococcal bacteremia in San Francisco residents. J Infect Dis 1990; 162: 1012-1017.

111. Schuchat A, Broome CV, Hightower A, Costa SJ, Parkin W. Use of surveillance for invasive pneumococcal disease to estimate the size of the immunosuppressed HIV-infected population. JAMA 1991; 265: 3275-3279.

112. Austrian R, Gold J. Pneumococcal bacteremia with especial reference to bacteremic pneumococcal pneumonia. Ann Intern Med 1964; 60: 759-776.

113. Breiman RF, Spika JS, Navarro VJ, Darden PM, Darby CP. Pneumococcal bacteremia in Charleston County, South Carolina. A decade later. Arch Intern Med 1990; 150: 1401-1405.

114. Garcia Leoni ME, Moreno S, Rodeno P, Cercenado E, Vicente T, Bouza E. Pneumococcal pneumonia in adult hospitalized patients infected with the human immunodeficiency virus. Arch Intern Med 1992; 152: 1808-1812.

115. Pesola GR, Charles A. Pneumococcal bacteremia with pneumonia. Mortality in acquired immunodeficiency syndrome. Chest 1992; 101: 150-155.

116. Hibbs JR, Douglas JM, Judson FN, McGill WL, Rietmeijer CAM, Janoff EN. Prevalence of human immunodeficiency virus infection, mortality rate, and serogroup distribution among patients with pneumococcal bacteremia at Denver General Hospital, 1984-1994. Clin Infect Dis 1997; 25: 195199.

117. Frankel RE, Virata M, Hardalo C, Altice FL, Friedland G. Invasive pneumococcal disease: clinical features, serotypes, and antimicrobial resistance patterns in cases involving patients with and without human immunodeficiency virus infection. Clin Infect Dis 1996; 23: 577-584.

118. Cohn DL. Bacterial pneumonia in the HIV-infected patient. Infect Dis Clin North Am 1991; 5: 485-507.

119. French N, Gilks CF, Mujugira A, Janoff EN. Impact of febrile illness among patients wth HIV-1 disease in Uganda. Proceedings of 37th ICAAC 1997; 37: I-155.

120. French N, Nakiyingi J, Carpenter L et al. Lack of efficacy of 23-valent pneumococcal polysaccharide vaccine in HIV-1infected Ugandan adults. Proceedings of the Federation of Infection Society, 1998.

121. Rodriguez Barrados MC, Musher DM, Hamill RJ, Dowell M, Bagwell JT, Sanders CV. Unusual manifestations of pneumococcal infection in human immunodeficiency virus-infected individuals: the past revisited. Clin Infect Dis 1992; 14: 192199.

122. Janoff EN, Rubins JB. Invasive pneumococcal disease in the immunocompromised host. Microb Drug Resist 1997; 3: $215-232$.

123. Grigoriadis E, Gold WL. Pyogenic brain abscess caused by Streptococcus pneumoniae: case report and review. Clin Infect Dis 1997; 25: 1108-1112.

124. Crewe-Brown HH, Karstaedt AS, Lance Saunders G et al. Streptococcus pneumoniae blood culture isolates from patients with and without Human Immunodeficiency Virus infection: alterations in penicillin susceptibilities and in serogroups or serotypes. Clin Infect Dis 1997; 25: 11651172 .

125. Paul J, Kimari J, Gilks CF. Streptococcus pneumoniae resistant to penicillin and tetracycline associated with HIV seropositivity. Lancet 1995; 346: 1034-1035. 
126. Scott JAG, Hall AJ, Hannington A et al. Serotype distribution and prevalence of resistance to benzylpenicillin in three representative populations of Streptococcus pneumoniae isolates from the coast of Kenya. Clin Infect Dis 1998; 27: $1442-1450$

127. The National Institute of Child Health and Human Development Intravenous Immunoglobulin Study Group. Intravenous immune globulin for the prevention of bacterial infections in children with symptomatic human immunodeficency virus infection. $N$ Engl J Med 1991; 325: 73-80.

128. Caiaffa WT, Graham NMH, Vlahov D. Bacterial pneumonia in adult populations with Human Immunodeficiency Virus (HIV) infection. Am J Epidemiol 1993; 138: 909-922.

129. Janoff EN, Fasching C, Ojoo JC, O'Brien J, Gilks CF. Responsiveness of human immunodeficiency virus type 1infected Kenyan women with or without prior pneumococcal disease to pneumococcal vaccine. J Infect Dis 1997; 175: 975-978.

130. French N, Gilks CF, Mujugira A, Fasching C, O’Brien J, Janoff EN. Pneumococcal vaccination in HIV-1-infected adults in Uganda: humoral response and two vaccine failures. AIDS 1998; 12: 1683-1689.

131. Carson PJ, Schut RL, Simpson ML, O'Brien J, Janoff EN. Antibody class and subclass responses to pneumococcal polysaccharides following immunization of human immunodeficiency virus-infected patients. $J$ Infect Dis 1995; 172: $340-345$.

132. Janoff EN, Douglas JM J, Gabriel M et al. Class-specific antibody response to pneumococcal capsular polysaccharides in men infected with human immunodeficiency virus type 1 . $J$ Infect Dis 1988; 158: 983-990.

133. Rodriguez-Barrados MC, Musher DM, Lahart $\mathrm{C}$ et al. Antibody to capsular polysaccharides of Streptococcus pneumoniae after vaccination of human immunodeficiency virus-infected subjects with 23 -valent pneumococcal vaccine. J Infect Dis 1992; 165: 553-556.

134. Vandenbruaene M, Colebunders R, Mascart-Lemone $\mathrm{F}$ et al. Equal IgG antibody response to pneumococcal vaccination in all stages of human immunodeficiency virus disease. $J$ Infect Dis 1995; 172: 551-553.

135. Ahmed F, Steinhoff MC, Rodriguez-Barrados MC, Hamilton RG, Musher DM, Nelson KE. Effect of human immunodeficiency virus type 1 infection on the antibody response to a glycoprotein conjugate pneumococcal vaccine: results from a randomized trial. J Infect Dis 1996; 173: 83-90.

136. Edge MD, Rimland D. Community-acquired bacteremia in HIV-positive patients: protective benefit of co-trimoxazole. AIDS 1996; 10: 1635-1639.

137. Mayer HB, Rose DN, Cohen S, Gurtman AC, Cheung TW, Szabo S. The effect of Pneumocystis carinii pneumonia prophylaxis regimens on the incidence of bacterial infections in HIV-infected patients. AIDS 1993; 7: 1687-1688.

138. Tumbarello M, Tacconelli E, Cauda R, Ortona L. Secondary Pneumocystis carinii pneumonia prophylaxis with trimethoprim-sulphamethoxazole does not prevent bacterial pneumonia in HIV-infected persons. AIDS 1996; 10: 1603-1604.

139. Gebo KA, Moore RD, Keruly JC, Chaisson RE. Risk factors for pneumococcal disease in human immunodeficiency virusinfected patients. $J$ Infect Dis 1996; 173: 857-862.

140. Anglaret $X$, Chene G, Attia A, Toure S, Nidri-yoman T, Salamon R. Early Co-trimoxazole chemoprophylaxis for HIVinfected adults in Africa: a double blind placebo-controlled trial, Abidjan, Ivory Coast. Proceedings of the 12th World AIDS Conference, 1998: 6.

141. Sassan-Morroko M, Wiktor SZ, Abouya L et al. Significant reduction in mortality attributable to co-trimoxazole prophylaxis among HIV-infected tuberculosis patients in Abidjan, Ivory Coast. Proceedings of the 12th World AIDS Conference, 1998: 5 .

142. Hyams JS, Dubin WA, Grand RJ, Goldman DA. Salmonella bacteremia in the first year of life. J Pediatr 1980; 96: 5759.

143. Meadow WL, Schneider H, Beem MO. Salmonella enteritidis bacteremia in childhood. J Infect Dis 1985; 152: 185-189.

144. Lepage P, Bogaerts J, Van Goethem C et al. Communityacquired bacteraemia in African children. Lancet 1987; 1: 1458-1461.

145. Mabey DCW, Brown A, Greenwood BM. Plasmodium falciparum malaria and salmonella infections in Gambian children. J Infect Dis 1987; 155: 1319-1321.

146. Green SDR, Cheesbrough JS. Salmonella bacteraemia among young children at a rural hospital in western Zaire. Ann Trop Paediatr 1993; 13: 45-53.

147. Graham SM, Walsh AM, Molyneux EM, Phiri A, Molyneux ME. The clinical presentation of non-typhoidal salmonella bacteraemia in Malawian children. Trans $R$ Soc Trop Med Hyg 2000 (in press)

148. Gendrel D, Kombila M, Beaudoin-Leblevec G, RichardLenoble D. Non-typhoidal salmonella septicemia in Gabonese children infected with Schistosoma intercalatum. Clin Infect Dis 1994; 18: 103-105.

149. Vugia DJ, Kiehlbauch JA, Yeboue K. Pathogens and predictors of fatal septicemia associated with human immunodeficiency virus infection in Ivory Coast, West Africa. $J$ Infect Dis 1993; 168: 564-570.

150. Kariuki S, Gilks C, Corkill J et al. Multi-drug resistant nontyphi salmonellae in Kenya. J Antimicrob Chemother 1996; 38: $425-434$

151. De Wit S, Taelman H, Van de Perre P, Rouvroy D, Clumeck N. Salmonella bacteremia in African patients with human immunodeficiency virus infection. Eur J Clin Microbiol Infect Dis 1998; 7: 45-47.

152. Gordon MA, Walsh AL, Chaponda M et al. Bacteraemia and mortality among adult medical admissions in Malawi predominance of non-typhi salmonellae and Streptococcus pneumoniae. J Infect 2000 (in press).

153. Gruenewald R, Blum S, Chan J. Relationship between human immunodeficiency virus infection and salmonellosis in 20- to 59-year-old residents of New York City. Clin Infect Dis 1994; 18: $358-363$.

154. Levin WC, Buehler JW, Bean NH, Tauxe RV. Epidemiology of non-typhoidal Salmonella bacteremia during the human immunodeficiency virus epidemic. J Infect Dis 1991; 164: 81-87.

155. Ferndández Guerrero ML, Torres Perrea R, Gómez Rodrigo J, Núñez Garcia A, Jusdado JJ, Ramos Rincón JM. Infectious endocarditis due to non-typhi Salmonella in patients with human immunodeficiency virus: report of two cases and review. Clin Infect Dis 1996; 22: 853-855.

156. Aliaga L, Mediavilla JD, Lopez de la Osa A, López-Gómez M, de Cueto M, Miranda C. Nontyphoidal Salmonella intracranial infections in HIV-infected patients Clin Infect Dis 1997; 25: 1118-1120.

157. Sperber SJ, Schluepner CJ. Salmonellosis during infection with human immunodeficiency virus. Rev Infect Dis 1987; 9: 925-934

158. Casado JL, Navas E, Frutos B et al. Salmonella lung involvement in patients with HIV infection. Chest 1997; 112: 1197-1201.

159. Casado JL, Valdezate S, Calderon C et al. Zidovudine therapy protects against Salmonella bacteremia recurrence in human immunodeficiency virus-infected patients. J Infect Dis 1999; 179: $1553-1556$

160. Wray C, McLaren IM, Jones YE. The epidemiology of Salmonella typhimurium in cattle: plasmid profile analysis of definitive phage type (DT) 204c. J Med Microbiol 1998; 47: 483-487.

161. Fone DL, Barker RM. Associations between human and farm animal infections with Salmonella typhimurium DT 104 in Herefordshire. Commun Dis Rep CDR Rev 1994; 4: R136R140.

162. Humphrey TJ. Food and milk-borne zoonotic infections. $J$ Med Microbiol 1997; 46: 11-13, 28-33.

163. Kariuki S, Gilks C, Kimari J, Muyodi J, Waiyaki P, Hart CA Analysis of Salmonella enterica serotype Typhimurium by phage typing, antimicrobial susceptibility and pulsed-field gel electrophoresis. J Med Microbiol 1999; 48: 1037-1042.

164. Threlfall EJ, Frost JA, Ward LR, Rowe B. Epidemic in cattle and humans of Salmonella typhimurium DT 104 with chromosomally integrated multiple drug resistance. Vet Rec 1994; 134: 577.

165. Threlfall EJ, Ward LR, Rowe B. Resistance to ciprofloxacin in non-typhoidal salmonellae in England and Wales. The current situation. Clin Microbiol Infect 1999; 5: 130-134.

166. Hacker J, Blum-Oehler G, Mühldorfer I, Tschäpe $H$. Pathogenicity islands of virulent bacteria: structure, function and impact on microbial evolution. Mol Microbiol 1997; 23 : 1089-1097. 
167. Hueck CJ. Type III protein secretion systems in bacterial pathogens of animals and plants. Microbiol Mol Biol Rev 1998; 62: 379-433.

168. Mills DM, Bajaj V, Lee CA. A $40 \mathrm{~kb}$ chromosomal fragment encoding Salmonella typhimurium invasion genes is absent from the corresponding region of the Escherichia coli $\mathrm{K}-12$ chromosome. Mol Microbiol 1995; 15: 749-759.

169. Shea JE, Hensel M, Gleeson C, Holden DW. Identification of a virulence locus encoding a second type III secretion system in Salmonella typhimurium. Proc Natl Acad Sci USA 1996; 93: $2593-2597$.

170. Blanc-Potard A-B, Groisman EA. The Salmonella selC locus contains a pathogenicity island mediating intramacrophage survival. EMBO J 1997; 16: 5376-5385.

171. Wong K-K, McClelland M, Stillwell LC, Sisk EC, Thurston SJ, Saffer JD. Identification and sequence analysis of a $27-$ kilobase chromosomal fragment containing a Salmonella pathogenicity island located at 92 minutes on the chromosome map of Salmonella enterica serovar Typhimurium LT2. Infect Immun 1998; 66: 3365-3371.

172. Wood MW, Jones MA, Watson PR, Hedges S, Wallis TS, Galyov EE. Identification of a pathogenicity island required for Salmonella enteropathogenicity. Mol Microbiol 1998; 29. 883-891.

173. Nesbitt A, Mirza NB. Salmonella septicaemias in Kenyan children. J Trop Pediatr 1989; 35: 35-39.

174. Gracey M, Ostergaard P, Beaman J. Oropharyngeal microflora in Aboriginal and non-Aboriginal Australian children: an indicator of environmental contamination. Med J Austr 1979; 2: $212-214$.

175. Gracey M, Stone DE, Suharjano, Sunoto. Oro-pharyngeal microflora in malnourished children. Austral Paediatr J 1973; 9: $260-262$.

176. Vazquez-Torres A, Jones-Carson J, Bäumler AJ et al. Extraintestinal dissemination of Salmonella by CD18-expressing phagocytes. Nature 1999; 401: 804-808.

177. de Jong R, Altare F, Haagen I-A et al. Severe mycobacterial and Salmonella infections in interleukin-12 receptor-deficient patients. Science 1998; 280: 1435-1438.

178. Altare F, Lammas D, Revy $\mathrm{P}$ et al. Inherited interleukin 12 deficiency in a child with bacille Calmette-Guerin and Salmonella enteritidis disseminated infection. J Clin Invest 1998; 102: 2035-2040.

179. Chehimi J, Starr SE, Frank I et al. Impaired interleukin 12 production in human immunodeficiency virus-infected patients. J Exp Med 1994; 179: 1361-1366.

180. Clerici M, Wynn TA, Berzofsky JA et al. Role of interleukin10 in T-helper cell dysfunction in asymptomatic individuals infected with the human immunodeficiency virus. $J$ Clin Invest 1994; 93: 768-775.

181. Searle S, Bright NA, Roach TI et al. Localization of Nramp1 in macrophages: modulation with activation and infection. $J$ Cell Sci 1998; 111: 2855-2866.

182. Carpenter CCJ, Fischl MA, Hammer SM et al. Antiretroviral therapy for HIV infection in 1998. Updated recommendations of an International AIDS Society - USA Panel. JAMA 1998; 280: $78-86$.

183. Moyle GJ, Gazzard BG, Cooper DA, Gatall J. Antiretroviral therapy for HIV infection. A knowledge-based approach to drug selection and use. Drugs 1998; 55: 383-404.

184. Department of Pharmacology, University of Liverpool, UK Drug interactions. 1999. http://www.liv.ac.uk/hivgroup.

185. Dudley MN. Clinical pharmacokinetics of nucleoside antiretroviral agents. J Infect Dis 1995; 171 Suppl 2: S99-S112.

186. Foster RH, Faulds D. Abacavir. Drugs 1998; 55: 729-736.

187. Acosta EP, Page LM, Fletcher CV. Clinical pharmacokinetics of zidovudine: an update. Clin Pharmacokinet 1996; 30: 251262.

188. Sim SM, Back DJ, Breckenridge AM. The effect of various drugs on the glucuronidation of zidovudine (azidothymidine; AZT) by human liver microsomes. $\mathrm{Br} J$ Clin Pharmacol 1991; 32: 17-21.

189. Barry M, Gibbons S, Back D, Mulcahy F. Protease inhibitors in patients with HIV disease: clinically important pharmacokinetic considerations. Clin Pharmacokinet 1997; 32: 194209.

190. Stretcher BN, Pesce AJ, Hurtubise PE, Frame PT. Pharmacokinetics of zidovudine phosphorylation in patients infected with the human immunodeficiency virus. Ther Drug Monit
1992; 14: 281-285.

191. Furman PA, Fyfe JA, St Clair MH. Phosphorylation of $3^{\prime}-$ azido-3'-deoxythymidine and selective interaction of the $5^{\prime}$ triphosphate with human immunodeficiency virus reverse transcriptase. Proc Natl Acad Sci USA 1986; 83: 8333-8337.

192. Lipsky JJ. Antiretroviral drugs for AIDS. Lancet 1996; 348 800-803.

193. Gao W-Y, Shirasaka T, Johns DG, Broder S, Mitsuya H. Differential phosphorylation of azidothymidine, dideoxycytidine, and dideoxyinosine in resting and activated peripheral blood mononuclear cells. J Clin Invest 1993; 91: 2326-2333.

194. Havlir DV, Friedland G, Pollard R et al. Combination zidovudine (ZDV) and stavudine (d4T) therapy versus other nucleosides: report of two randomised trials ACTG 290 and 298 [abstract]. 5th Conference on Retroviruses and Opportunistic Infections, Chicago, IL, 1998.

195. Hoggard PG, Veal GJ, Wild MJ, Barry MG, Back DJ. Drug interactions with zidovudine phosphorylation in vitro. Antimicrob Agents Chemother 1995; 39: 1376-1378.

196. Veal GJ, Barry MG, Back DJ. Zalcitabine (ddC) phosphorylation and drug interactions. Antiviral Chem Chemother 1995; 6: 379-384.

197. Kewn S, Veal GJ, Hoggard PG, Barry MG, Back DJ. Lamivudine (3TC) phosphorylation and drug interactions in vitro. Biochem Pharmacol 1997; 54: 589-595.

198. Gao W-Y, Johns DG, Mitsuya H. Anti-human immunodeficiency virus type-1 activity of hydroxyurea in combination with 2',3'-dideoxynucleosides. Mol Pharmacol 1994; 46: $767-772$.

199. Rutschmann OT, Opravil M, Iten A et al. A placebocontrolled trial of didanosine plus stavudine, with and without hydroxyurea, for HIV infection. The Swiss HIV Cohort Study. AIDS 1998; 12: F71-F77.

200. Perry CM, Balfour JA. Didanosine. An update on its antiviral activity, pharmacokinetic properties and therapeutic efficacy in the management of HIV disease. Drugs 1996; 52: 928 962.

201. Eagling VA, Back DJ, Barry MG. Differential inhibition of cytochrome $\mathrm{P} 450$ isoforms by the protease inhibitors, ritonavir, saquinavir and indinavir. $\mathrm{Br} J$ Clin Pharmacol 1997; 44: 190-194.

202. Williams PEO, Muirhead GJ, Madigan MJ, Mitchell AM, Shaw T. Disposition and bioavailability of the HIV-proteinase inhibitor, Ro 31-8959, after single doses in healthy volunteers. Br J Clin Pharmacol 1992; 34: 155P-156P

203. Hoffman-La Roche. Fortivase ${ }^{\mathrm{TM}}$ (saquinavir) soft gelatin capsules. Prescribing information. 1997.

204. Barry M, Feely J. Enzyme induction and inhibition. Pharmacol Ther 1990; 48: 71-94.

205. Kumar GN, Rodrigues AD, Buko AM, Denissen JF. Cytochrome P450-mediated metabolism of the HIV-1 protease inhibitor ritonavir (ABT-538) in human liver microsomes. $J$ Pharmacol Exp Ther 1996; 277: 423-431.

206. Merry C, Barry MG, Mulcahy F et al. Saquinavir pharmacokinetics alone and in combination with ritonavir in HIVinfected patients. AIDS 1997; 11: F29-F33.

207. Buss N, on behalf of the F study group. Saquinavir soft gel capsule (Fortovase) pharmacokinetics and drug interactions [abstract]. 5th Conference on Retroviruses and Opportunistic Infections, Chicago, IL, 1998.

208. Merry C, Barry MG, Mulcahy F, Halifax KL, Back DJ. Saquinavir pharmacokinetics alone and in combination with nelfinavir in HIV-infected patients. AIDS 1997; 11: F117F120.

209. Murphy RL, Montaner J. Nevirapine: A review of its development, pharmacological profile and potential for clinical use. Expert Opin Invest Drugs 1996; 5: 1183-1199.

210. Sahai J, Cameron W, Salgo $\mathrm{M}$ et al. Drug interaction study between saquinavir (SQV) and nevirapine (NVP) [abstract]. 4th Conference on Retroviruses and Opportunistic Infections, Washington, DC, 1997.

211. Cox SR, Ferry JJ, Batts DH et al. Delavirdine and marketed protease inhibitors: pharmacokinetic interaction studies in healthy volunteers [abstract]. 4th Conference on Retroviruses and Opportunistic Infections, Washington, DC,1997.

212. von Moltke LL, Greenblatt DJ, Grassi JM et al. Protease inhibitors as inhibitors of human cytochromes P450: high risk associated with ritonavir. J Clin Pharmacol 1998; 38: 106111. 
213. Perry CM, Noble S. Saquinavir soft-gel capsule formulation. A review of its use in patients with HIV infection. Drugs 1998; 55: 461-486.

214. Thiebaut F, Tsuruo T, Hamanda H, Gottesman MM, Pastan I, Willingham MC. Cellular localisation of the multidrug resistance gene product P-glycoprotein in normal human tissues. Proc Natl Acad Sci USA 1987; 84: 7735-7738.

215. Wacher VJ, Wu C-Y, Benet LZ. Overlapping substrate specificities and tissue distribution of cytochrome P450 3A and p-glycoprotein: implications for drug delivery and activity in cancer chemotherapy. Mol Carcinog 1995; 13: 129-134.

216. Maurice M, Pichard L, Daujat M et al. Effects of imidazole derivatives on cytochrome $\mathrm{P} 450$ from human hepatocytes in primary culture. FASEB $J$ 1992; 6: $752-758$.

217. Hsu A, Granneman GR, Japour AJ et al. Evaluation of potential ritonavir and indinavir combination BID regimens [abstract A-57]. 37th Interscience Conference on Antimicrobial Agents and Chemotherapy, Toronto, 1997.

218. Anonymous. Viracept prescribing information. 1997. Agournon Pharmaceuticals, La Jolla, CA, USA.

219. Yuen G, Anderson R, Daniels R, Kerr B. Investigations of nelfinavir mesylate (NFV) pharmacokinetic (PK) interactions with indinavir (IDV) and ritonavir (RTV) [abstract]. 4th Conference on Retroviruses and Opportunistic Infections, Washington, DC, 1997.

220. Merry C, Barry MG, Mulcahy F et al. Ritonavir pharmacokinetics alone and in combination with saquanivir in HIVinfected patients. AIDS 1998; 12: 325-327.

221. Lea AP, Faulds D. Ritonavir. Drugs 1996; 52: 541-546.

222. Bonnabry P, Rasca AF, Leeman TJ JL, Dayer P. Prediction of in vivo impairment of cytochrome $\mathrm{P} 450$-mediated metabolism by HIV protease inhibitors [abstract 12390]. 12th World AIDS Conference, Geneva, Switzerland, 1998.

223. Burger DM, Hugen PWH, Prins JM et al. Pharmacokinetics of an indinavir/ritonavir $800 / 100 \mathrm{mg}$ BID regimen [abstract]. 6th Conference on Retroviruses and Opportunistic Infections, Chicago, 1999.

224. DuPont Merck. Sustiva Product Information. 1997.

225. Sadler BM, Eron J, Wakeford J et al. Pharmacokinetics of $141 \mathrm{~W} 94$ and indinavir (IDV) after single-dose coadministration in HIV-positive volunteers [abstract A-56]. 37th Interscience Conference on Antimicrobial Agents and Chemotherapy, Toronto, 1997.

226. Jarvis B, Faulds D. Nelfinavir: a review of its therapeutic efficacy in HIV infection. Drugs 1998; 56: 147-167.

227. Zhang $\mathrm{K}$, Wu E, Patick A et al. Plasma metabolites of nelfinavir, a potent HIV protease inhibitor, in HIV positive patients: quantification by LC-MS/MS and antiviral activities [abstract 128]. 6th ISSX, 1997.

228. Cox SR, Scheck DW, Herman BD et al. Delavirdine (DLV) and nelfinavir (NFV); a pharmacokinetic (PK) drug-drug interaction study in healthy adult volunteers1 [abstract]. 5th Conference on Retroviruses and Opportunistic Infections, Chicago, 1998.

229. Sadler BM, Gillotin C, Chittick GE et al. Pharmacokinetics drug interactions with amprenavir [abstract 12389]. 12th World AIDS Conference, Geneva, Switzerland, 1998.

230. Piscitelli SC, Vogel S, Sadler BM et al. Effect of efavirenz (DMP266) on the pharmacokinetics of 141W94 in HIV infected patients [abstract]. 5th Conference on Retroviruses and Opportunistic Infections, Chicago, 1998.

231. Robinson P, Gigliotti M, Lamson M et al. Effect of the reverse transcriptase inhibitor, nevaripine, on the steady state pharmacokinetics of clarithromycin in HIV positive patients [abstract 374]. 6th Conference on Retroviruses and Opportunistic Infections, Chicago, 1999.

232. Ferry JJ, Herman BD, Cox SR, Carlson GF. Delavidine (DLV) and indinavir (IDV); a pharmacokinetic (PK) drug-drug interaction study in healthy adult volunteers [abstract]. 4th Conference on Retroviruses and Opportunistic Infections, Washington, DC, 1997.

233. Shelton MJ, Hewitt RG, Adams JM et al. Delavirdine (DLV) mesylate pharmacokinetics (PK) during combination therapy with ritonavir (RIT) [abstract]. 5th Conference on Retroviruses and Opportunistic Infections, Chicago, 1998.

234. Acosta EP, Gulick RM, Katzenstein DA et al. Pharmacokinetic (PK) evaluation of saquinavir soft gel capsules (SQV)/ritonavir (RTV) or SQV/nelfinavir in combination with delavirdine (DLV) and/or adefovir dipivoxil (ADV) ACTG 359 [abstract 365]. 6th Conference on Retroviruses and Opportunistic Infections, Chicago, 1999.

235. Morse GD, Fischl MA, Shelton MJ et al. Single-dose pharmacokinetics of delavirdine mesylate and didanosine in patients with human immunodeficiency virus infections. Antimicrob Agents Chemother 1997; 41: 169-174.

236. Fiske WD, Benedek IH, White SJ et al. Pharmacokinetic interaction between efevirenz (EFV) and nelfinavir mesylate (NFV) in healthy volunteers. 5th Conference on Retroviruses and Opportunistic Infections, Chicago, 1998.

237. Fiske WD, Benedek IH, Joseph JL et al. Pharmacokinetics of efavirenz (EFV) and ritonavir (RIT) after multiple oral doses in healthy volunteers [abstract 42269]. 12th World AIDS Conference, Geneva, Switzerland, 1998. 